\title{
HIF-1-driven skeletal muscle adaptations to chronic hypoxia: molecular insights into muscle physiology
}

\author{
F. B. Favier ${ }^{1,2}$ - F. A. Britto ${ }^{1,2}$ - D. G. Freyssenet ${ }^{3} \cdot$ X. A. Bigard ${ }^{4} \cdot$ H. Benoit ${ }^{5,6}$
}

\begin{abstract}
Skeletal muscle is a metabolically active tissue and the major body protein reservoir. Drop in ambient oxygen pressure likely results in a decrease in muscle cells oxygenation, reactive oxygen species (ROS) overproduction and stabilization of the oxygen-sensitive hypoxia-inducible factor (HIF)-1 $\alpha$. However, skeletal muscle seems to be quite resistant to hypoxia compared to other organs, probably because it is accustomed to hypoxic episodes during physical exercise. Few studies have observed HIF-1 $\alpha$ accumulation in skeletal muscle during ambient hypoxia probably because of its transient stabilization. Nevertheless, skeletal muscle presents adaptations to hypoxia that fit with HIF-1 activation, although the exact contribution of HIF-2, I kappa B kinase and activating transcription factors, all potentially activated by hypoxia, needs to be determined. Metabolic alterations result in the inhibition of fatty acid oxidation, while activation of anaerobic glycolysis is less evident. Hypoxia causes mitochondrial remodeling and enhanced mitophagy that ultimately lead to a decrease in ROS production, and this acclimatization in turn contributes
\end{abstract}

\section{F. B. Favier}

favier@supagro.inra.fr

1 INRA, UMR 866 Dynamique Musculaire et Métabolisme, 34060 Montpellier, France

2 Université de Montpellier, 34090 Montpellier, France

3 Laboratoire de Physiologie de l'Exercice EA 4338, Université de Lyon, Université Jean Monnet, 42000 Saint Etienne, France

4 Agence Française de Lutte contre le Dopage, 75007 Paris, France

5 INSERM, U1042 Hypoxie Physio-Pathologie, 38000 Grenoble, France

6 Université Joseph Fourier, 38000 Grenoble, France to HIF-1 $\alpha$ destabilization. Likewise, hypoxia has structural consequences with muscle fiber atrophy due to mTOR-dependent inhibition of protein synthesis and transient activation of proteolysis. The decrease in muscle fiber area improves oxygen diffusion into muscle cells, while inhibition of protein synthesis, an ATP-consuming process, and reduction in muscle mass decreases energy demand. Amino acids released from muscle cells may also have protective and metabolic effects. Collectively, these results demonstrate that skeletal muscle copes with the energetic challenge imposed by $\mathrm{O}_{2}$ rarefaction via metabolic optimization.

Keywords Altitude - Atrophy ·

Hypoxia inducible factor - Metabolism - Mitochondria .

Oxidative stress

\section{Introduction}

Skeletal muscle is the most voluminous tissue of the body as it represents almost $40 \%$ of body weight and it accounts for a significant part (20-30\%) of basal metabolic rate [1]. Skeletal muscle is a heterogeneous tissue composed of fibers that have distinct contractile and metabolic properties. Type I fibers (also named slow oxidative) are mitochondria-rich cells with high myoglobin content and capillary density responsible for their red colour. Type IIX and IIB fibers (fast glycolytic) have generally larger crosssection area with higher glycolytic machinery and are less perfused, while type IIA (fast oxidative) exhibit an intermediary profile. More than $90 \%$ of the energy produced by muscle cells comes from the aerobic pathway. A reduction in $\mathrm{O}_{2}$ availability would therefore challenge skeletal muscle homeostasis. This situation will be exacerbated in case of physical exercise, as it will enhance ATP demand. 
Reduced $\mathrm{O}_{2}$ pressure (hypobaric hypoxia) and sustained exercise are experienced by alpinists and mountaineers, and skeletal muscle adaptations in these subjects have been studied for several decades. Pioneering works evidenced the negative effect of hypoxia exposure on skeletal muscle mass. However, hypoxia is not only restricted to mountaineers or high altitude residents, and could result from pathologies such as anemia, vascular abnormalities, heart failure, chronic obstructive pulmonary disease or sleep apnea. Since reduced muscle mass and/or altered metabolism may be associated with enhanced fatigability, sedentary lifestyle and ultimately increased risk of mortality, the fine understanding of molecular responses driven by skeletal muscle hypoxia is of particular interest for athletes, active people, as well as patients. This review attempts to depict the molecular mechanisms underlying skeletal muscle adaptations to chronic hypoxia (i.e. several days) in healthy subjects.

\section{Defining hypoxia and $\mathrm{O}_{2}$ sensing pathway}

\section{Intramuscular $\mathrm{O}_{2}$ pressure}

The first question when dealing with hypoxia is to define what hypoxia means for the cells. Hypoxia literally means under/below oxygen that we could translate by "less oxygen" or even under oxygenation compared to physiological level. Hypoxic environment can be experimentally reproduced by decreasing the proportion of $\mathrm{O}_{2}$ available in ambient air (normobaric hypoxia), therefore reducing the inspired $\mathrm{O}_{2}$ fraction $\left(\mathrm{FIO}_{2}\right)$ from the normal value of $20.9 \%$. Another way is to decrease the barometric pressure leading to the reduction in $\mathrm{O}_{2}$ availability while its proportion into the inspired air remains constant (hypobaric hypoxia). A correspondence between the common altitude levels used in publications, the $\mathrm{FIO}_{2}$, the ambient and inspired $\mathrm{O}_{2}$ pressure is presented in Table 1. The definition

Table 1 Correspondence between the inspired $\mathrm{O}_{2}$ fraction $\left(\mathrm{FIO}_{2}\right)$, the altitude level and the ambient $\mathrm{O}_{2}$ pressure

\begin{tabular}{lcll}
\hline $\mathrm{FIO}_{2}(\%)$ & Altitude $(\mathrm{m})$ & $\begin{array}{l}\text { Ambient } \mathrm{PO}_{2} \\
(\mathrm{mmHg})\end{array}$ & $\begin{array}{l}\text { Inspired } \mathrm{PO}_{2} \\
(\mathrm{mmHg})\end{array}$ \\
\hline 20.9 & 0 & 159 & 149 \\
15 & 2700 & 114 & 107 \\
12 & 4400 & 91 & 86 \\
10 & 5800 & 76 & 71 \\
8 & 7400 & 61 & 57 \\
6 & 9400 & 46 & 43 \\
1 & 19,500 & 8 & 7 \\
\hline
\end{tabular}

The reduction of $\mathrm{PO}_{2}$ between ambient and inspired air is due to the saturation with water vapor in the upper airway of hypoxia raises the issue of a threshold in $\mathrm{O}_{2}$ pressure $\left(\mathrm{PO}_{2}\right)$ that will place the cell in hypoxic condition. Data obtained from magnetic resonance spectroscopy experiments (human) [2, 3], via optical method (rat) [4], surface electrode ( $\mathrm{dog}$ ) [5] or microcatheter (human) [6] lead to resting intramuscular $\mathrm{PO}_{2}$ of $\approx 27 \mathrm{mmHg}$ in normoxic conditions. Few data exist on intramuscular $\mathrm{PO}_{2}$ during hypoxia: Johnson et al. reported a value of $\approx 10 \mathrm{mmHg}$ after $1 \mathrm{~min}$ of breathing $7 \% \mathrm{O}_{2}$ (equivalent to $8300 \mathrm{~m}$ ) in rat cremaster muscle [4], while Richardson's group found more than double $(23 \mathrm{mmHg})$ in humans with an inspired $\mathrm{O}_{2}$ fraction of $10 \%(\approx 5800 \mathrm{~m})$ [2]. During exercise of even slight intensity (unweighted knee extension at $30 \%$ of maximal leg $\mathrm{O}_{2}$ uptake), $\mathrm{PO}_{2}$ rapidly drop to $\approx 5 \mathrm{mmHg}$ [3]. There are only subtle changes in intramuscular $\mathrm{PO}_{2}$ between very light and heavy exercise as $\mathrm{PO}_{2}$ decreases to $3 \mathrm{mmHg}$ at $50 \%$ of maximal leg $\mathrm{O}_{2}$ uptake and remains constant until maximal work rate. During hypoxic trial $\left(\mathrm{FIO}_{2}=12 \%\right), \quad \mathrm{PO}_{2}$ still decreases and reaches $\approx 2 \mathrm{mmHg}$. More recently, Masschelein et al. showed that muscle oxygenation, assessed by near-infrared spectroscopy, was modestly but significantly reduced $(\approx 5 \%)$ in subjects breathing $10.7 \% \mathrm{O}_{2}$ [7]. In the same work, tissue oxygenation index was decreased just after a moderate intensity exercise performed in normoxia $(\approx 6 \%)$ and this decrement was slightly enhanced in hypoxia $(\approx 9 \%)$. Mitochondrion is the final destination of $\mathrm{O}_{2}$ into muscle cells. In skeletal muscle fiber, the $\mathrm{PO}_{2}$ at which mitochondrial metabolism becomes inhibited is about $1.25 \mathrm{mmHg}$ [8], that is far lower to what it could be encountered in hypoxic resting muscle. Altogether, it can be concluded that exercise per se induces significant reduction of muscle cell $\mathrm{PO}_{2}$ and this diminution is worsened by hypoxic environment. Secondly, the effect of hypoxic exposure seems less potent than muscle work to decrease cellular oxygenation, although the knowledge on how hypoxia alters muscle $\mathrm{PO}_{2}$ at rest is minimal. In tumors, it has been proposed that expression of hypoxia-regulated genes increases at $\mathrm{PO}_{2}$ below $10-15 \mathrm{mmHg}$. Energy metabolism would be impaired at $\mathrm{PO}_{2}$ less than $10-8 \mathrm{mmHg}$, and apoptosis would be stimulated at less than $1 \mathrm{mmHg}[9,10]$. Skeletal muscle is probably more resistant to low $\mathrm{O}_{2}$ levels as ATP production is maintained during exercise and it is currently not possible to set a value that would mark the occurrence of cellular hypoxic state. One can only point that long term residency of humans seems to be critical beyond $5500 \mathrm{~m}$ above sea level, suggesting that whole body oxygenation becomes critical for chronic exposure at this altitude.

\section{Hypoxia-inducible factor (HIF) activation}

The best way to characterize muscle cell hypoxia is to look at the cellular response. Since the article of Wang and 
Semenza in 1992 [11], Hypoxia inducible factor (HIF) 1 has been described as the master regulator of hypoxiamediated cellular adaptations. This $\alpha / \beta$ heterodimeric transcription factor regulates more than 100 genes involved in erythropoiesis/iron metabolism, angiogenesis, vascular tone, matrix metabolism, glucose metabolism, cell proliferation/survival or apoptosis [12]. Accordingly, Hifla $a^{+/-}$ heterozygous mice (total deletion is lethal [13]) exhibit impaired physiological responses to chronic hypoxia, including alterations in erythropoiesis, pulmonary vascular remodeling and ventilatory adaptations $[14,15]$.

While HIF-1 $\beta$ (also known as ARNT) is constitutively expressed, HIF- $1 \alpha$ protein is quickly degraded in normoxic conditions (half-life $<1 \mathrm{~min}$ [16]). This degradation is mediated via hydroxylation of proline residues on HIF- $1 \alpha$ by prolyl-hydroxylases (PHD) leading to its binding to the von Hippel-Lindau (pVHL) tumour suppressor, ubiquitinylation and subsequent degradation by the proteasome (Fig. 1). A similar mechanism involving asparagine residue hydroxylation by Factor Inhibiting HIF (FIH) silences HIF$1 \alpha$ transactivation domain through inhibition of the transcription coactivators (p300 and CBP) recruitment in normoxia [17]. PHD-dependent regulation of HIF-1 $\alpha$ implies the presence of $\mathrm{O}_{2}$ and 2-oxoglutarate as substrates and $\mathrm{Fe}^{2+}$ as co-factor. Under reduced $\mathrm{O}_{2}$ pressure, PHD are inhibited because of the lower $\mathrm{O}_{2}$ availability, but also via the conversion of $\mathrm{Fe}^{2+}$ into $\mathrm{Fe}^{3+}$ due to mitochondrial reactive oxygen species (ROS) production from the complex III of the electron transport chain [18]. Consistently, data from Chaudhary et al. [19] show a strong relation between HIF- $1 \alpha$ protein content and free radical generation in hypoxic rat muscle (Fig. 2). Inhibition of PHD results

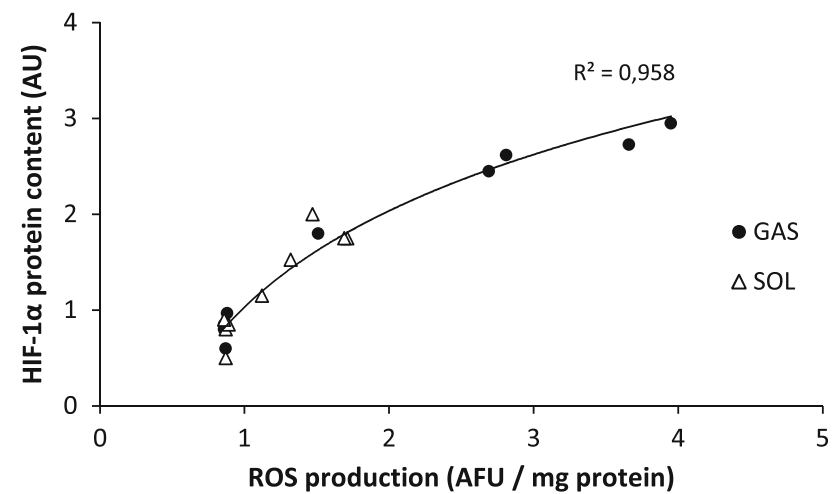

Fig. 2 HIF- $1 \alpha$ protein content correlates with free radical generation in skeletal muscle of rats exposed to extreme hypoxia. Rats were exposed for 3, 7, 14 or 21 days to a simulated altitude of $7620 \mathrm{~m}$. Higher rate of ROS generation was measured after 14 days in hypoxic environment. GAS gastrocnemius, SOL soleus. Redrawn from [19]

both in the stabilization and the dimerization of HIF- $1 \alpha$ with the $\beta$ subunit. Accordingly, hypoxia can be mimicked by iron chelation (e.g. deferoxamine), some transition metals (e.g. cobalt) or 2-oxoglutarate inhibitors (e.g. DMOG), and this property has been widely used to hypoxia preconditioning. While HIF- $1 \alpha$ is subjected to other posttranslationnal regulations such as acetylations, phosphorylations or nitrosylations (reviewed in [20]), inhibition of hydroxylation is the main regulation involved in hypoxiainduced HIF- $1 \alpha$ stabilization.

A specificity of muscle cells could reside in HIF- $1 \alpha$ nuclear translocation. Inhibition of HIF- $1 \alpha$ degradation by $\mathrm{CoCl}_{2}$ is sufficient to cause its nuclear accumulation in COS-7 cells, whereas this translocation requires low oxygen levels in primary myotubes. The nuclear import of HIF- $1 \alpha$
Fig. 1 Regulation of HIF- $1 \alpha$ under normoxia and hypoxia. HIF- $1 \alpha$ associates with HIF-1 $\beta$ and p300/CBP, binds DNA and activates transcription under reduced $\mathrm{O}_{2}$. In presence of $\mathrm{O}_{2}$ and 2-oxoglutarate, prolylhydroxylases (PHD) and factor inhibiting HIF (FIH) hydroxylate HIF- $1 \alpha$ on prolines (Pro) 402 and 564 and on asparagine (Asn) 803, respectively. Asparagine hydroxylation $(\mathrm{OH})$ inhibits the association between HIF- $1 \alpha$ and p300/CBP, while prolines hydroxylation results in the binding to the E3 ubiquitin ligase Von Hippel-Lindau complex (VHL), leading to its degradation by the proteasome

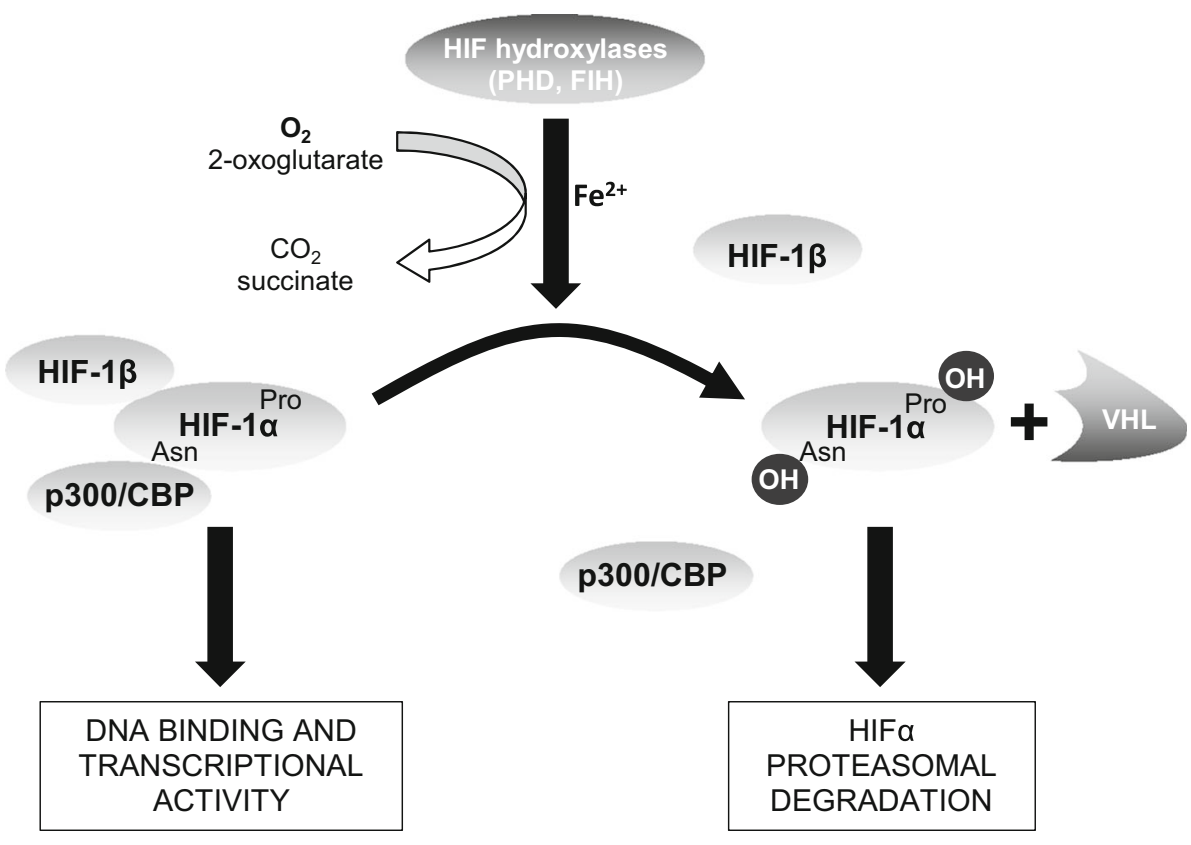


in muscle cells is concomitant with its dissociation from HSP90, a protein that has been proposed to mask the nuclear localization signal of HIF-1 $\alpha$ under normoxia [21]. Nuclear accumulation of pVHL has been observed in $\mathrm{C} 2 \mathrm{C} 12$ myotubes exposed to $1 \% \mathrm{O}_{2}$ and this translocation promotes HIF-1 $\alpha$ stabilization and transcriptional activity in 117 and 786-0 cells [22]. This mechanism was not induced by the decrease in $\mathrm{PO}_{2}$ per se, but rather results from the acidosis due to the enhancement in anaerobic glycolysis. This is of particular interest as skeletal muscle can experience metabolic acidosis during intense exercise. It should be noted that HIF- $1 \alpha$ can also be activated by growth factors or cytokines such as angiotensin II, insulin, Insulin-like growth factor (IGF), interleukin-1 or transforming growth factor $\alpha$ under normoxic conditions (reviewed in [12]). Intensive researches are engaged to decipher the cross-talk between HIF-1 and inflammation notably in the fields of cancer, obesity and metabolic disorders. Some works showed normoxic HIF-1 $\alpha$ activation through a Tumor Necrosis Factor- $\alpha /$ Nuclear Factor -kappa B axis [23], although the few data available in muscle cells do not support such a regulation [24]. As during hypoxia, ROS seem to play a key role for normoxic HIF-1 $\alpha$ activation [12].

The HIF family also comprises HIF-2 and HIF-3. HIF$2 \alpha$ protein is subjected to similar regulation by hypoxia than HIF- $1 \alpha$ and it is implicated in hypoxic response as it may confer muscle resistance to ischemia [25]. Yet, muscle HIF- $2 \alpha$ protein accumulation is low $6 \mathrm{~h}$ after ischemia and undetectable after endurance exercise [25, 26]. Moreover, it seems to have opposite effects on muscle phenotype compared to hypoxia and HIF- $1 \alpha$ activity (cf. below and [27]). Very few data exist on HIF-3 function and there are no studies in skeletal muscle. It has been shown that HIF$3 \alpha$ alternative splicing triggers it transcriptional activity on Hypoxia Response Elements [28] and one splice variant can bind and inhibit HIF- $1 \alpha$ activity [29]. Collectively, these results suggest that skeletal muscle adaptations consecutive to hypoxic exposure are mainly driven by HIF-1, though others transcription factors could be also activated during hypoxia and thus contribute to the whole adaptative response [30]. Microarray on wild-type and HIF-1 $\alpha$ knockout mouse embryonic fibroblasts (MEF) supports this hypothesis, since $89 \%$ of the genes induced after exposure to $1 \% \mathrm{O}_{2}$ were regulated by HIF-1 [31].

\section{Hypoxic stabilization of HIF-1 $\alpha$ in skeletal muscle: myth or reality?}

The characterization of HIF-1 response to hypoxia in vivo is limited because of technical outcomes. Extrapolation of results obtained from cultured cells to whole body is subjected to caution. Cell culture experiments use extreme conditions, as control cells could be hyperoxic $\left(20.9 \% \mathrm{O}_{2}\right.$ means an ambiant $\mathrm{PO}_{2}$ of $159 \mathrm{mmHg}$ that is far greater to that of capillaries) and the reduction in $\mathrm{O}_{2}$ availability is often drastic $\left(1 \% \mathrm{O}_{2}\right.$ in ambient air equal a $\mathrm{PO}_{2}$ of $7.6 \mathrm{mmHg}$ and probably less into the cells). Cell line (e.g. cancer vs. non cancer cells) is also of particular importance since it influences $\mathrm{O}_{2}$ availability into the medium. Some cell lines are thus hypoxic at $20.9 \% \mathrm{O}_{2}$ because of high cell density and metabolic rate [32]. This may explain why hypoxia exposure results in a modest increase in HIF- $1 \alpha$ protein expression in L6 rat myoblasts $\left(0.5 \% \mathrm{O}_{2}\right)$ or primary rabbit myotubes $\left(3 \% \mathrm{O}_{2}\right)[21,33]$.

Another major limitation is the short half-life of HIF- $1 \alpha$ that would theoretically impact (decrease) its protein content during tissue removal or cell harvest since they are generally performed under normoxic conditions. Recent advances have been made on this issue by using live cell imaging under hypoxia. For example, Bagnall et al. demonstrated that HIF- $1 \alpha$ protein is only transiently stabilized ( $3 \mathrm{~h}$ pulses) in HeLa cells exposed to $1 \% \mathrm{O}_{2}$ [34]. The authors showed that the short stabilization of HIF- $1 \alpha$ is due to the up-regulation of PHD2 (while HIF-2 $\alpha$ seems rather regulated by PHD1 [25]). When HIF-1 $\alpha$ protein expression is prolonged over this time lapse, cell engaged into a p53-related apoptosis program, although whether the same is true for muscle cells remains to be determined. It would be thus interesting to determine whether or not muscle PHD2 content increases during chronic hypoxia. This mechanism is likely because endurance trained subjects, whose muscles are submitted to intense hypoxic episodes during contractions, have increased PHD2 and FIH protein content in their vastus lateralis muscle [35]. Cigarette smoke exposure also increases PHD2 and pVHL protein expression in mouse skeletal muscle, concomitantly with reduced HIF-1 $\alpha$ content [36]. One may suppose that muscle HIF- $1 \alpha$ expression will return to basal level within a few hours even if the hypoxic environment persists as it has been observed in brain, liver and kidney [37]. Cell culture experiments support this assumption, since HIF- $1 \alpha$ protein peaked between 4 and $24 \mathrm{~h}$ of exposure to hypoxia $\left(1-2 \% \mathrm{O}_{2}\right)$ before returning to modest or undetectable levels in human myoblasts [38] and human induced pluripotent stem cells [39]. This could explain why gastrocnemius HIF-1 $\alpha$ level was not increased in erytropoietin-deficient mice with an hematocrit of $30 \%$ or in wild-type animals after $24 \mathrm{~h}$ or 14 days at $4500 \mathrm{~m}$ [40]. Skeletal muscle may also be low responder to reduced $\mathrm{O}_{2}$ delivery, as HIF luciferase reporter activity did not increase after acute anemia in skeletal muscle contrary to other organs such as brain, kidney or liver [41] and skeletal muscle deoxygenation was half the size of brain in subjects exposed to $12 \% \mathrm{O}_{2}$ for $4 \mathrm{~h}$ [42]. A last point that affects data about HIF- $1 \alpha$ protein expression is the cellular compartment used for western blot analysis. While HIF- $1 \alpha$ 
protein is usually undetectable in total muscle lysate, the nuclear fraction contains high amounts of HIF- $1 \alpha$ under normoxia [43], notably compared to others tissues [37]. Isolating the nuclear fraction would thus be helpful to characterize HIF- $1 \alpha$ protein response to reduced $\mathrm{O}_{2}$ availability.

In summary, hypoxia may be defined as a condition of low $\mathrm{O}_{2}$ pressure sufficient to promote HIF- $1 \alpha$ accumulation in the cells. A key signal for stabilizing HIF- $1 \alpha$ is the increase in ROS production, even more than the decrease in $\mathrm{O}_{2}$ pressure per se. Marked increase in HIF-1 $\alpha$ protein content has been observed in skeletal muscle during endurance exercise and/or blood restriction [26]. However, the stabilization of HIF-1 $\alpha$ after systemic hypoxia (e.g. altitude exposure) has not been systematically reported [40, 44] and seems rather modest (reviewed in [45]), except for severe hypoxia: $\mathrm{FIO}_{2}$ of $6 \%$ [37] or simulated altitude of $5800 \mathrm{~m}$ [46] and $7620 \mathrm{~m}$ [19]. Skeletal muscle HIF-1 $\alpha$ accumulation likely reflects severe impairment of whole body oxygenation and it would be of clinical interest to measure HIF- $1 \alpha$ accumulation in skeletal muscle of patients suffering from pathologies associated with hypoxemia (reduction in arterial $\mathrm{O}_{2}$ ) or decreased blood flow. Another explanation for the lack of muscle HIF- $1 \alpha$ accumulation under hypoxia is the transient nature of its stabilization. This raises an intriguing issue: how such a short up-regulation could have so durable consequences on muscle phenotype?

\section{Skeletal muscle metabolic adaptations in response to chronic hypoxia}

Pioneering work from Reynafarje in 1962 reported an increase in myoblogin content and higher cytochrome c reductase activity in skeletal muscle of highlanders, suggesting that prolonged hypoxia resulted in an enhancement of skeletal muscle oxidative capacity. However, further works that studied the effect of hypoxia independently from other factors, such as cold or exercise, showed that hypoxia per se promoted oxidative-to-glycolytic metabolic shift (see Table 2). Accordingly, expression of HIF- $1 \alpha$ is higher in glycolytic vs. oxidative muscles [47] and subjects carrying a mutation that leads to increased HIF- $1 \alpha$ stability have higher distribution of type II fibers [48]. This effect is related to the role of HIF-1 on muscle metabolism through several coordinated mechanisms.

\section{Hypoxia-mediated regulation of metabolic pathways}

HIF-1 up-regulates the expression of 11 glycolytic enzymes (aldolase A, aldolase C, enolase 1, glyceraldehyde-3-phosphate dehydrogenase, hexokinase 1 , hexokinase 2 , lactate dehydrogenase A, phosphofructokinase L, phosphoglycerate kinase 1, pyruvate kinase $\mathrm{M}$, and triosephosphate isomerase) contributing to enhance the glycolytic capacity of cells [49]. Although these targets have often been identified in nonmuscle cells, significant up-regulation of lactate dehydrogenase and hexokinase activity has been observed in skeletal muscle after hypoxia exposure (Table 2). Further analysis of the literature reveals that most activities of muscle glycolytic enzymes remain unchanged by hypoxia as recently reviewed [50]. Given that the glycolytic machinery can support strong increase in glycolysis at exercise in normoxia, one may suppose that there is no need to further upgrade the maximal capacity of this system under hypoxia (at least at rest). Muscle glycolytic capacity (assessed by lactate production under anoxia) was not enhanced after 1,16 or 90 days at $5500 \mathrm{~m}$ [51], confirming the marginal effect of chronic hypoxia on the anaerobic pathway in skeletal muscles of sedentary rats.

Besides, HIF-1 inhibits oxidative metabolism by restricting the entry of pyruvate into the tricarboxylic acid cycle [52], through the induction of the pyruvate dehydrogenase kinase (PDK) 1. PDK1 phosphorylates and inactivates the pyruvate dehydrogenase enzyme complex that converts pyruvate to acetyl-coenzyme $\mathrm{A}$ in the mitochondria. In muscle cells, PDK1 up-regulation has been reported in rats exposed to $10 \% \mathrm{O}_{2}$ for 2 weeks [46] and in human satellite cells treated with PHD inhibitor [35], but not in humans after 7-9 days at $4560 \mathrm{~m}$ [44]. This could be related to the kinetics of gene expression since $24 \mathrm{~h}$ of exposure to $4300 \mathrm{~m}$ was associated with increased PDK1 protein content while it returned to basal level after 1 week [53].

As a consequence of these regulations, muscle lactate production would be increased by hypoxia exposure. Yet, lactate concentration and lactate-to-pyruvate ratio were not elevated in the vastus lateralis of subjects exposed for either $4 \mathrm{~h}$ or 3 weeks at $4300 \mathrm{~m}[54,55]$, while lactate accumulation was increased in the media of $\mathrm{C} 2 \mathrm{C} 12$ myotubes $96 \mathrm{~h}$ after treatment with PHD inhibitor [35]. Skeletal muscle lactate efflux is notably mediated by MCT4, a monocarboxylate transporter that is upregulated during in vitro hypoxia in a HIF-1-dependent manner [56]. However, in vivo studies provided equivocal data with no change, increase or decrease in MCT4 expression [57-59]. Although extensively studied at exercise, regulation of lactate metabolism under reduced $\mathrm{O}_{2}$ availability is not yet fully elucidated.

HIF-1 also triggers oxidative metabolism by impairing fatty acid oxidation and mice lacking skeletal muscle HIF$1 \alpha$ display increased lipid oxidation [60]. HIF-1 reduces the DNA binding activity of peroxisome proliferator-activated receptor $\alpha(\mathrm{PPAR} \alpha) /$ retinoid $\mathrm{X}$ receptor complex, a major regulator of lipid oxidation [61-63]. Hypoxia also inhibits the PPAR $\gamma$ coactivator $1 \alpha$ (PGC- $1 \alpha)$ pathway in a HIF-1-dependent way in $\mathrm{C} 2 \mathrm{C} 12$ myotubes [64]. Along with the reduction in the transcriptional activity of the 
Table 2 Effect of hypoxia on the activity of metabolic enzymes in human (H), mouse (M) or rat (R) skeletal muscles

\begin{tabular}{|c|c|c|c|c|c|c|c|}
\hline \multirow{2}{*}{$\begin{array}{l}\text { Altitude } \\
(\mathrm{m})\end{array}$} & \multirow{2}{*}{$\begin{array}{l}\text { Duration } \\
\text { (days) }\end{array}$} & \multirow[t]{2}{*}{ Specie } & \multirow[t]{2}{*}{ Muscle } & \multicolumn{3}{|l|}{ Enzymatic activity } & \multirow[t]{2}{*}{ Reference } \\
\hline & & & & Increased & Unchanged & Decreased & \\
\hline \multirow[t]{2}{*}{2100} & 14 & $\mathrm{H}$ & GAS & & LDH & $\mathrm{CS} 13 \%$, HAD $10 \%$ & {$[141]$} \\
\hline & & & ТВ & & LDH, CS, HAD & & \\
\hline \multirow[t]{3}{*}{3700} & 63 & $\mathrm{R}$ & SOL & CS, PFK & HAD, HK, LDH & & {$[142]$} \\
\hline & 63 & $\mathrm{R}$ & PLA & & $\overline{\text { HK, LDH, PFK }}$ & $\mathrm{CS}, \underline{\mathrm{HAD}}$ & \\
\hline & 63 & $\mathrm{R}$ & QUA & & CS, HAD, HK, LDH & PFK & \\
\hline 3800 & 7 & M & $\begin{array}{l}\text { Lower } \\
\text { hindlimb }\end{array}$ & & $\mathrm{CS}, \overline{\mathrm{HAD}}$ & СРТ $50 \%$ & [67] \\
\hline \multirow[t]{5}{*}{4000} & 35 & $\mathrm{R}$ & SOL & & $\mathrm{CS}$ & HAD $51 \%$ & {$[86]$} \\
\hline & & & & & & CPT $34 \%$ & \\
\hline & 84 & $\mathrm{R}$ & SOL & HK $40 \%$ & CS, LDH & $\overline{\mathrm{HAD} 10 \%}$ & {$[143]$} \\
\hline & 84 & $\mathrm{R}$ & EDL & LDH $10 \%$ & CS, HK & $\underline{\text { HAD } 16 \%}$ & \\
\hline & 84 & $\mathrm{R}$ & PLA & $\begin{array}{l}\text { HK } 39 \%, \text { LDH } \\
18 \%\end{array}$ & $\mathrm{CS}$ & HAD $12 \%$ & \\
\hline 4100 & 56 & $\mathrm{H}$ & VL & & LDH-H & & {$[57]$} \\
\hline \multirow[t]{5}{*}{4300} & 18 & $\mathrm{H}$ & VL & HK $19 \%$ & GP, LDH, MDH & & [144] \\
\hline & 21 & $\mathrm{H}$ & VL & $\begin{array}{l}\text { HK } 16 \% \text {, PFK } \\
13 \%\end{array}$ & $\underline{\mathrm{HAD}}, \mathrm{SDH}$ & & {$[55]$} \\
\hline & 35 & $\mathrm{R}$ & EDL & & $\mathrm{CS}$ & СPT $62 \%$ & [145] \\
\hline & 35 & $\mathrm{R}$ & SOL & & CPT & & \\
\hline & 35 & $\mathrm{R}$ & QUA & & & HAD $31 \%$ & \\
\hline \multirow[t]{2}{*}{4878} & 28 & $\mathrm{R}$ & SOL & & LDH, PK, HK, CS, MDH & & [146] \\
\hline & 28 & $\mathrm{R}$ & PLA & & LDH, PK, HK, CS, MDH & & \\
\hline 5350 & 70 & $\mathrm{H}$ & $\mathrm{VL}$ & & & $\mathrm{COX}, \mathrm{CS}$ & [147] \\
\hline \multirow[t]{5}{*}{5500} & 12 & $\mathrm{R}$ & PLA & & & $\operatorname{CS} 13 \%, \operatorname{COX} 41 \%$ & {$[65]$} \\
\hline & 56 & & & & & CS $16 \%, \operatorname{COX} 36 \%$ & \\
\hline & 21 & $\mathrm{R}$ & PLA & LDH-H $26 \%$ & LDH (9 \%), LDH-M & & [59] \\
\hline & & & SOL & $\begin{array}{l}\text { LDH } 38 \%, \text { LDH-M } \\
\quad 100 \%\end{array}$ & LDH-H & & \\
\hline & 90 & $\mathrm{R}$ & GAS & & LDH & & {$[51]$} \\
\hline \multirow[t]{4}{*}{5800} & 14 & $\mathrm{R}$ & GAS & PK & $\mathrm{CS}$ & $\mathrm{MDH}$ & [46] \\
\hline & 14 & $\mathrm{R}$ & GAS & & & COX $55 \%$, CS $73 \%$ & [148] \\
\hline & 21 & $\mathrm{R}$ & SOL & HK $44 \%$ & CS, HAD, LDH, PFK, PK & & [149] \\
\hline & 21 & $\mathrm{R}$ & GAS & & $\mathrm{CS}$ & & \\
\hline 6000 & 18 & $\mathrm{H}$ & $\mathrm{VL}$ & LDH $13 \%$ & $\mathrm{CS}$ & & {$[150]$} \\
\hline 6100 & 7 & $\mathrm{R}$ & GAS & LDH $54 \%$ & $\begin{array}{l}\frac{\mathrm{CPT}, \mathrm{CS}(-19 \%), \underline{\mathrm{HAD}}(-14 \%)}{\mathrm{MDH}, \mathrm{SDH}}\end{array}$ & & {$[66]$} \\
\hline 8848 & 40 & $\mathrm{H}$ & VL & & 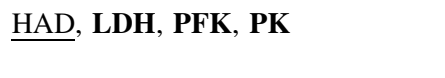 & $\begin{array}{l}\text { CS } 29 \%, \text { HK } 38 \% \\
\text { SDH } 28 \%\end{array}$ & [91] \\
\hline
\end{tabular}

Glycolytic enzymes are in bold and enzymes specific from lipid oxidation are underlined. The percent changes (increase or decrease) are indicated when available

Muscles: $E D L$ extensor digitorum longus, GAS gastrocnemius, $P L A$ plantaris, $Q U A$ quadriceps, $S O L$ soleus, $T B$ triceps brachii, $V L$ vastus lateralis

Enzymes: $C O X$ cytochrome oxydase, $C P T$ carnitine palmitoyl transferase, $C S$ citrate synthase, $G P$ glycogen phosphorylase, $H A D$ hydroxyacylCoA dehydrogenase, $H K$ hexokinase, $L D H$ lactate dehydrogenase ( $\mathrm{H}$ or $\mathrm{M}$ : heart or muscle isoform), $M D H$ malate dehydrogenase, $P F K$ phosphofructokinase, $P K$ pyruvate kinase, $S D H$ succinate dehydrogenase

PPAR/PGC- $1 \alpha$ complex, hypoxia can also result in a decrease in PPAR $\alpha$ and PGC-1 $\alpha$ protein content $[63,65]$, although there are some discrepancies regarding PGC- $1 \alpha$ expression (e.g. protein vs. mRNA levels [65]). Since PPAR $\alpha$ and PGC- $1 \alpha$ are major regulators of fatty acid metabolism, hypoxia leads to a decrease in mitochondrial 
import and $\beta$-oxidation of fatty acids. This is notably illustrated by a decrease in carnitine palmitoyl transferase and hydroxyacyl-coenzyme A dehydrogenase activity that has frequently been reported (Table 2). The overall effect of hypoxia logically resulted in a marked reduction of fatty acid oxidation after 1 week in hypoxic environment [66, 67].

\section{Mitochondrial remodelling and regulation of ROS production}

Mountaineers which participated to expeditions in the Himalayas (Lhotse or Everest) presented diminished mitochondrial content [68], with subsarcolemmal mitochondria being more affected than the intermyofibrillar subpopulation [69]. People living permanently at high altitude (Tibetans and Quechuans) have also reduced mitochondrial content in skeletal muscle suggesting that this phenotype is conserved with long term adaptation [70]. Cellular models demonstrated that hypoxic exposure causes mitochondrial autophagy in an HIF-1-dependent way [71]. Autophagy is a process involving the formation of autophagosomes and this mechanism is initiated by the dissociation of the Beclin1/Bcl-2 complex. HIF-1 mediates the increase in BNIP3 expression during hypoxia exposure in skeletal muscle [72-74]. BNIP3 competes with Beclin1 for binding to Bcl-2 leading to the release of Beclin1 [75], thus promoting the initiation of autophagy and mitophagy.
This process could also be initiated by activation of the metabolic sensor Sirt1, whose expression is increased during hypoxia in a HIF-dependent manner in Hep3B or HT1080 cells [76]. Activation of mitochondrial autophagy through a Sirt1/BNIP3 pathway attenuated hypoxia-associated renal damage [77]. This suggests that the removal of altered mitochondria is required to limit oxidative damages. A recent study showed that the mitochondrial ubiquitin ligase 1 (Mul1) targeted the mitochondrial fusion protein mitofusin-2 resulting in mitophagy during muscle wasting [78]. Whether or not Mul1 expression is increased during hypoxia remains however to be elucidated. Taken together, all these mechanisms reduce the metabolic contribution of mitochondria and increase the involvement of the glycolytic pathway to energy supply (Fig. 3). In agreement, skeletal muscle specific deletion of HIF-1 $\alpha$ results in an increase in oxidative capacity and mitochondrial density, a reduction in serum lactate concentration and enhanced performances during endurance exercise [79]. The physiological significance of this shift toward glucose utilization is a decrease in $\mathrm{O}_{2}$ reliance since (1) stimulation of glycolysis flux increases anaerobic ATP synthesis and (2) glucose rather fatty acid oxidation is advantageous when looking at the $\mathrm{P} / \mathrm{O}$ ratio (i.e. the ATP produced relative to the amount of $\mathrm{O}_{2}$ consumed).

Another major point concerning the issue of hypoxiamediated mitochondrial remodelling is the regulation of ROS production. Reduced $\mathrm{O}_{2}$ availability promotes ROS

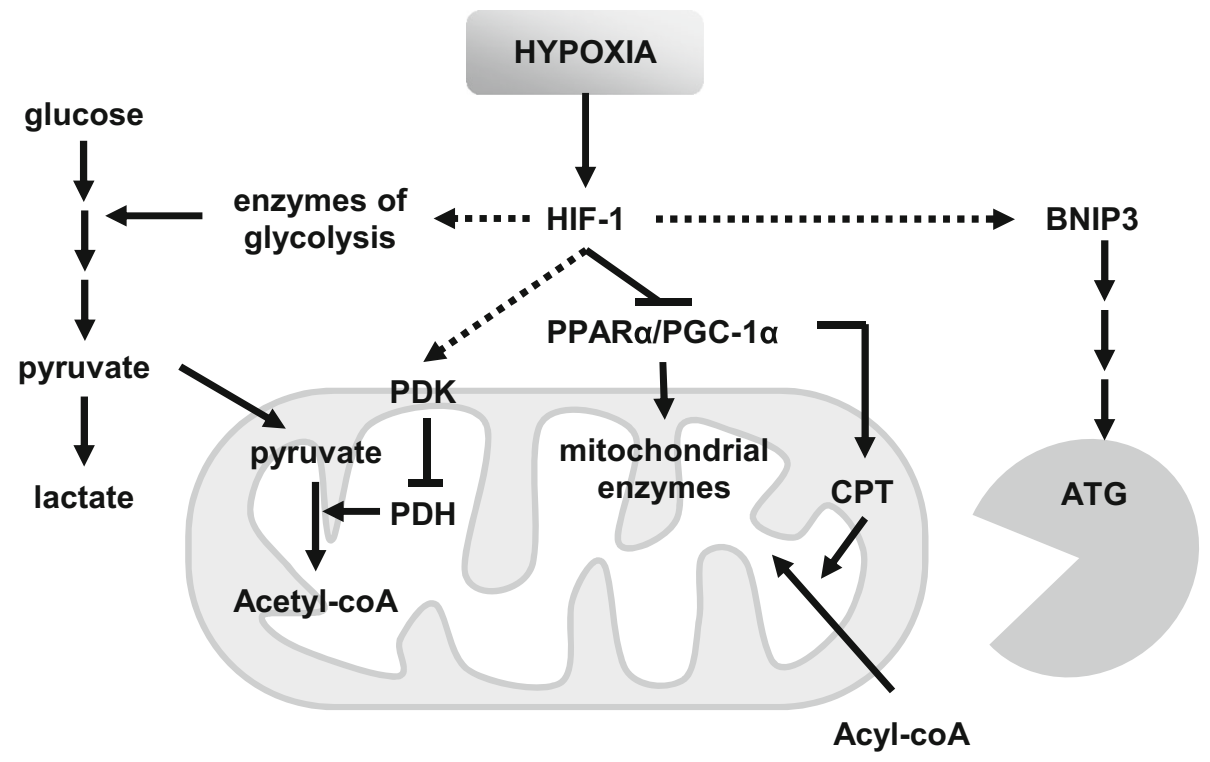

Fig. 3 Metabolic adaptations of skeletal muscle cell exposed to hypoxia. HIF-1 coordinately regulates muscle metabolism through (1) enhanced transcription of glycolytic enzymes, (2) repression of lipid oxidation via inhibition of PPAR/PGC- $1 \alpha$ axis and (3) reduction in mitochondrial content by induction of the BNIP3-dependent mitophagy. ATG mitochondrial autophagy, BNIP3 BCL2/adenovirus E1B
$19 \mathrm{kDa}$ protein-interacting protein $3, C P T$ carnitine palmitoyltransferase, HIF-1 hypoxia-inducible factor 1, $P D H$ pyruvate dehydrogenase, $P D K$ pyruvate dehydrogenase kinase, $P G C-1 \propto$ PPAR $\alpha$ coactivator $1-\alpha, P P A R \alpha$ peroxisome proliferator-activated receptor $\alpha$. Dotted arrows represent transcriptional regulations 
formation, and excessive ROS production represents a risk of oxidative damage that could lead to cell death if not corrected. Hypoxia exposure therefore results in cellular adaptations to counteract oxidative stress-induced damages. The importance of regulating ROS production under hypoxia was evidenced by the use of HIF- $1 \alpha$ deficient MEFs. These cells died after $72 \mathrm{~h}$ in hypoxic environment due to a dramatic increase in ROS levels contrary to control cells that reduced $\mathrm{H}_{2} \mathrm{O}_{2}$ production [52]. At the mitochondrial level, $\mathrm{O}_{2}$ is used by the cytochrome c oxidase (COX) complex. HIF-1 has been shown to up-regulate the expression of both COX4-2 subunit and LON, a mitochondrial protease targeting COX4-1 in cultured cells [80]. This switch from COX4-1 to COX4-2 leads to the improvement in the electron transfer and thus reduction in $\mathrm{O}_{2}^{--}$production. Increased UCP3 expression has also been reported after hypoxia exposure [81, 82], and this also contributes to impair ROS production. The miRNA miR210 is a direct target of HIF-1 and its deletion enhances ROS production and decreases survival upon $\mathrm{H}_{2} \mathrm{O}_{2}$ treatment of $\mathrm{C} 2 \mathrm{C} 12$ myotubes [83]. These adaptations together with the degradation of damaged mitochondria by autophagy would thus decrease ROS production. As ROS are involved in HIF- $1 \alpha$ stabilization (see above), this reduction would suppress HIF-1 $\alpha$ accumulation consistently with its transient up-regulation observed in vitro [34]. Muscle proteome of highlanders is characterized by reinforced protection against ROS compared to control subjects permanently residing at low altitude [84], and hypoxia preconditioning by $\mathrm{CoCl}_{2}$ in rats reduced exercise-induced skeletal muscle oxidative damages [85]. Altogether, this confirms that regulation of redox status under reduced $\mathrm{O}_{2}$ availability is of key importance.

Mitochondrial function is depreciated in rodents exposed to simulated altitude, even when $\mathrm{O}_{2}$ consumption was normalized to mitochondrial protein content [86-88]. Unexpectedly, mitochondrial respiration was only modestly altered in humans exposed to $4550 \mathrm{~m}$ with slight reduction in maximal oxidative phosphorylation capacity [89]. This result is all the more surprising in that $\mathrm{O}_{2}$ consumption was expressed per mg of muscle, which therefore does not take into account the potential decrease in mitochondrial density. Another difference between this latter study and the formers is that it was performed on permeabilized fibers and not on isolated mitochondria. Since this in situ approach appears to be more relevant from a physiological view, it would be interesting to confirm this result.

\section{Skeletal muscle vascularization}

Oxidative metabolism of muscle cells is tightly related to blood perfusion and muscular capillarity. Capillarization, as measured by the capillary density, is substantially and consistently increased in skeletal muscles of both humans and rats after exposure to hypobaric hypoxia of long duration [90-92]. An increase in muscle capillarity could be explained by the transcription of the Vascular Endothelial Growth Factor (VEGF) by HIF-1 $\alpha$. VEGF has even been characterized as "the" gene inducible by hypoxia and/or HIF- $1 \alpha$. Overexpression of both HIF- $1 \alpha$ and HIF- $2 \alpha$ promotes angiogenesis in mouse heart and rabbit ischemic skeletal muscle [93]. However, accumulating evidence suggest that VEGF mRNA is not systematically elevated throughout the exposition to hypoxia and may be even decreased after chronic exposure [94]. No study evidenced an increase in the number of capillaries per fiber in sedentary muscles e.g. [68, 90-92, 94-97] and it is now admitted that ambient hypoxia per se does not promote capillary neoformation [45, 98]. The reason of the potential higher capillary density resides in the reduction of the fiber crosssectional area, as hypoxia may cause skeletal muscle atrophy, resulting in an enhanced capacity for oxygen diffusion.

\section{Regulation of muscle mass}

\section{Structural modifications}

The negative effect of altitude on muscle mass has been objectivized since the 80 's. While this negative influence was thought to be primarily related to cold exposure, high energy expenditure and especially hypophagia [99], we and others have demonstrated that hypoxia per se accounts for skeletal muscle atrophy $[74,100,101]$. Although numerous differences exist between studies (altitude level, normobaric vs. hypobaric hypoxia, exposure duration, age of animals and acclimatization duration), analysis of published data clearly shows a significant positive correlation between hypoxia severity and the level of muscle atrophy in rats (Fig. 4a). Of note, muscle atrophy occurs at altitude higher than 5000-5500 m. One may suppose that oxidative muscles would be more affected by hypoxia as they are highly dependent from $\mathrm{O}_{2}$ delivery, although glycolytic ones are generally more sensitive to atrophy [102-104]. Based on the Fig. $4 \mathrm{a}$, it is however not clear whether muscle typology impacts susceptibility to hypoxia (see also [105]). Analysis of changes in the mean fiber cross-sectional area confirms the worsening of muscle atrophy under severe hypoxia (Fig. 4b). Type II fibers appear to be greatly affected by hypoxia, as recently suggested [106], although this assumption is dampened by the heterogeneity of data. A greater susceptibility of type II fibers to hypoxia may be explained by an already low $\mathrm{O}_{2}$ diffusion capacity resulting from high cross sectional area and poor capilarization. 

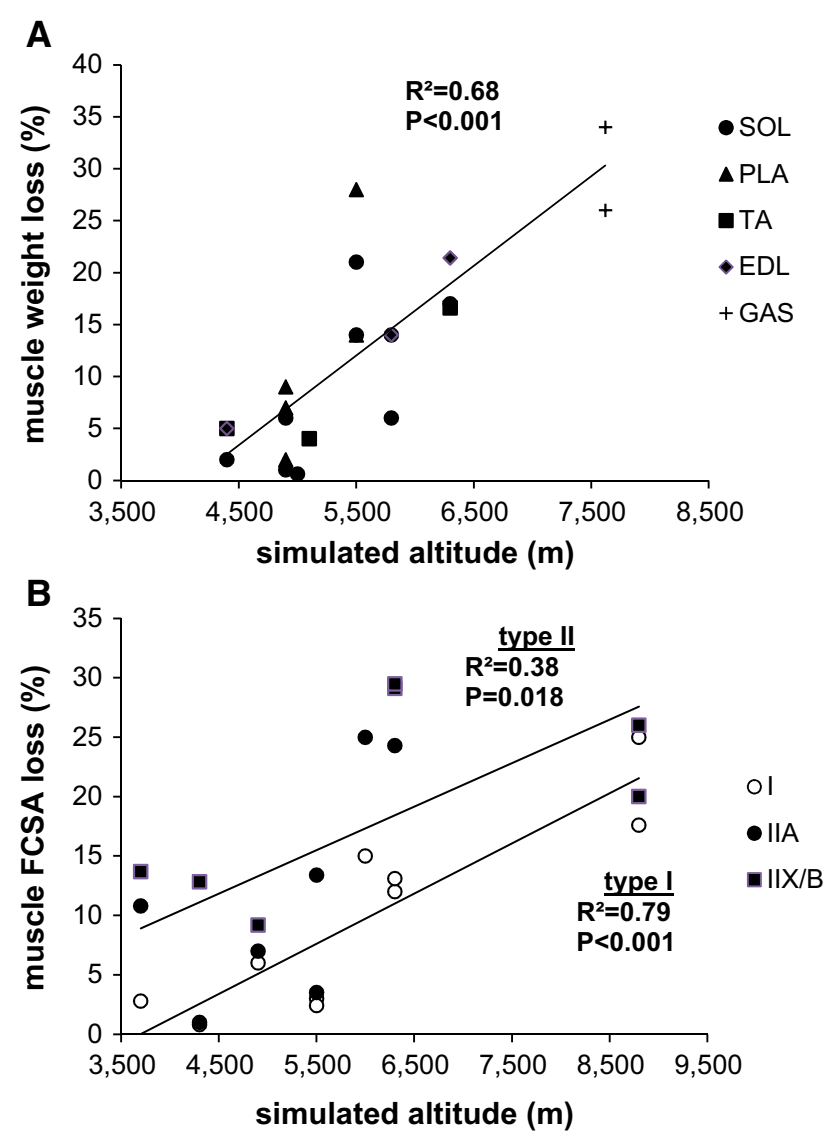

C

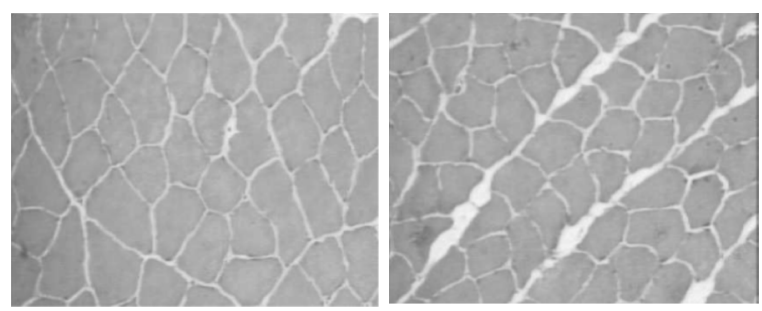

Fig. 4 Skeletal muscle atrophy in rats and humans exposed to simulated altitude between 1 and 6 weeks. a muscle weight (rats only) and $\mathbf{b}$ fiber cross-sectional area (FCSA) reduction (rats and humans) in function to simulated altitude level (hypobaric and normobaric hypoxia). Type IIX/B fibers measured at $8848 \mathrm{~m}$ are indeed undifferentiated type II fibers. c, d representative pictures from hematoxylin-eosin stained cross sections of rat plantaris muscle $\mathbf{c}$ in normoxia or $\mathbf{d}$ after 12 days at $5500 \mathrm{~m}$ (obtained from [118] with permission). Data for muscle weight and FCSA were obtained from [19, 101, 118, 123, 146, 149, 151-155] and [55, 91, 96, 101, 142, 151,153, 155], respectively

Assuming that myofibrillar proteins represent about $85 \%$ of the fiber volume [107], the regulation of skeletal muscle mass is closely related to dynamic balance between protein synthesis and degradation. Cellular experiments reveal that a marked reduction in $\mathrm{O}_{2}$ availability decreases the rate of protein synthesis in various cell lines including C2C12 myoblasts [108]. In rats, Preedy et al. observed a non-significant decrease in muscle protein synthesis
(14-17\%) after $6 \mathrm{~h}$ at $10 \% \mathrm{O}_{2}$ [109]. Data in humans are scarce and are often biased by confounding factors such as cold exposure or increased physical activity (trekking) in the days preceding the analysis $[110,111]$. Etheridge et al. showed that acute hypoxia had no effect on fractional synthesis rate of myofibrillar proteins at rest, whereas it blunted the anabolic effect of resistance exercise [112]. Interestingly, protein synthesis level was correlated to arterial saturation suggesting that severe hypoxemia would affect muscle anabolism.

\section{$\mathrm{O}_{2}$-sensitive signaling in the control of muscle mass}

Activity of the Akt/mTOR pathway is a critical regulator of muscle mass by regulating protein synthesis (via the mTOR complex 1: TORC1) and proteolysis [113, 114]. We reported a down-regulation of Akt/mTOR pathway after hypoxic exposure in rats [101]. One explanation of this inhibition could be a reduction in insulin-like growth factor (IGF) 1 expression, the upstream regulator of Akt/mTOR pathway. Nevertheless, IGF-1 mRNA or protein do not present significant variations under sustained hypoxia $[19$, 101]. We recently observed that hypoxia blocked IGF-1mediated activation of the $\mathrm{Akt} / \mathrm{mTOR}$ pathway in $\mathrm{C} 2 \mathrm{C} 12$ myotubes [115]. On the contrary, the expression of myostatin, a muscle-secreted factor which reduces muscle mass through inhibition of the Akt/mTOR pathway [116, 117], is increased by hypoxia exposure [106, 118, 119]. Inhibition of myostatin signaling (antibody administration, receptor inhibition or genetic ablation) partly prevents muscle atrophy under hypoxic conditions, further demonstrating that myostatin contributes to hypoxia-mediated muscle wasting [105, 119]. Loss in food intake due to hypoxia could also increase glucocorticoids pathway with the induction of KLF15 expression [106], a glucocorticoid receptor target involved in amino acid degradation to provide carbohydrate backbones for gluconeogenesis. Other circulating factors such as cytokines or adipokines may be released during hypoxia exposure, notably because of the loss of adipose tissue. However, analysis of blood cytokines profile [e.g. Tumor Necrosis Factor- $\alpha$, Interleukin (IL)-1 $\beta$, adiponectin, chemokine (C-C motif) ligand 5 , monocyte chemoattractant protein-1] did not reveal any marked alteration with hypoxia, with the exception of an increase in IL-6 content [120]. From this study, cytokines do no seems to be implicated in hypoxia-induced muscle atrophy, although further work is required to decipher their influence on muscle phenotype.

The Akt/mTOR pathway is also regulated by AMP-activated kinase (AMPK), which causes TORC1 inhibition [121]. The $\alpha$ catalytic subunit of AMPK is activated when cellular energy levels are low and stimulates processes that generate ATP (fatty acid oxidation), while inhibiting those 
that use ATP (triglyceride and protein synthesis). In subjects exposed to $11.5 \% \mathrm{O}_{2}$ for $20 \mathrm{~min}$, Wadley et al. did not reported any alteration of skeletal muscle AMPK $\alpha 1$ activity, AMPK $\alpha 2$ activity, AMPK $\alpha$ Thr172 phosphorylation, or ACC $\beta$ Ser221 phosphorylation (a direct target of AMPK) [122]. While AMPK can be transiently activated by acute hypoxia, this activation does not seem to persist after several days at altitude [73, 101, 118, 123]. These observations are consistent with the stability of AMP, ADP and ATP concentrations after 21 days at $4300 \mathrm{~m}$ [55] and do not support a role for AMPK in Akt/mTOR inhibition during skeletal muscle hypoxia in vivo.

Another negative regulator of TORC1 is the stress response protein REDD1 (for regulated in development and DNA damages). REDD1 has a low level of expression in skeletal muscle under basal conditions, while its expression is strongly induced by glucocorticoid and is required for glucocorticoid-induced muscle atrophy [124]. REDD1 is a direct target of HIF-1 and its expression in skeletal muscle is increased in response to hypoxia [7, 101, 118, 125]. It would therefore be a potential candidate to explain muscle loss at altitude even if REDD1 expression does not always correlate with mTOR inhibition [7, 118]. Its biological function is likely not restricted to protein metabolism, since it localizes into the mitochondria and triggers ROS production in cultured cells [126].

BNIP3 has also been proposed to inhibit mTOR through its interaction with Rheb [127]. This mechanism still needs to be confirmed as BNIP3-mediated inhibition of mTOR has never been reproduced in skeletal muscle or during hypoxia. Protein translation could also be down-regulated in a TORC1-independent way via the inhibition of the initiation factor eIF2. While eIF2-related inhibition of protein synthesis has been well characterized in tumorigenic cells [128], the few studies investigating such a mechanism in skeletal muscle do not support this hypothesis [74, 125].

In summary, hypoxia-driven reduction in skeletal muscle protein synthesis mostly results from the de-activation of the Akt/mTOR pathway consequently to upregulation of myostatin or REDD1.

\section{Hypoxia-related regulation of proteolytic systems}

Muscle protein breakdown mainly results from activation of the ubiquitin/proteasome system (UPS) and the autophagy/lysosome pathway, both processes being controlled by the Akt/mTOR signaling. The TORC2/Akt axis triggers the expression of the E3-ligases MAFbx and MuRF1 or other components of the UPS through FoxOs cytosolic sequestration. Only few experiments investigated UPS activation under reduced $\mathrm{O}_{2}$ conditions and results regarding enzymatic activity of the $20 \mathrm{~S}$ proteasome remain discordant [19, 101]. Kinetics is likely of particular importance when studying these markers. Some works reported an increase in MAFbx mRNA [74, 119], while this expression in not always observed after prolonged exposure [101, 123]. The other well studied E3 ligase MuRF1 presents a similar expression pattern with an increase during the first week of hypoxia exposure $[74,123]$ and a return to basal level during longer exposure [101, 123]. These patterns of MuRF1 and MAFbx expression in response to hypoxia are similar to those reported during unloading and muscle inactivity [129]. Nedd4, another E3 ligase that promotes skeletal muscle atrophy, has recently been shown to be involved in hypoxic response in lung [130]. Accordingly, Nedd4 expression was increased in EDL (but not in soleus) muscle of rodents exposed to $8 \%$ $\mathrm{O}_{2}$ [106]. While increase in MuRF1 and MAFbx expression could be related to the semi-starvation induced by hypoxia, Nedd4 regulation seems to be only dependent from $\mathrm{O}_{2}$ pressure. Other E3 ligases such as TRAF6, MUSA-1 or Trim32 participate to the control of muscle mass [129], but knowledge about their regulation under hypoxia is minimal.

Autophagy is stimulated via different mechanisms among which the activation of ULK1 resulting from TORC1 inhibition. Hypoxia exposure has been associated with an increase in the expression of autophagic markers such as BNIP3 [72-74] or LC3 [74]. As mentioned above, activation of muscle mitophagy under hypoxic environment seems evident. However, the involvement of autophagy in the control of muscle mass during hypoxia exposure has not been extensively described and remains to be characterized.

ATF4 [131], ATF3 [132] and IкB kinase [133] are directly regulated by PHDs in non-muscle cells and may thus play a role in cellular response to $\mathrm{O}_{2}$ deprivation independently from the HIFs pathways. ATF4 could be of particular interest since it promotes muscle atrophy [134, 135] and its mRNA was increased in the gastrocnemius of mice exposed to severe hypoxia [74]. Activation of IкB kinase in hypoxic muscle would increase Nuclear Factor $\kappa \mathrm{B}(\mathrm{NF}-\kappa \mathrm{B})$ transcriptional activity, and NF- $\kappa \mathrm{B}$ is known to promote muscle wasting through stimulation of UPSmediated protein breakdown [136]. Studying the contribution of these transcription factors to muscle remodeling during hypoxia would thus be helpful to better understand signals that trigger skeletal muscle atrophy.

A transient activation of proteolysis together with a sustained reduction in protein synthesis would be advantageous to cope with the energetic challenge induced by hypoxia. On the one hand, protein synthesis is a highly ATP-consuming process accounting for $\approx 25 \%$ of the total metabolic rate [1]. On the other hand, a transient activation of proteolytic systems would promote a rapid decrease in 


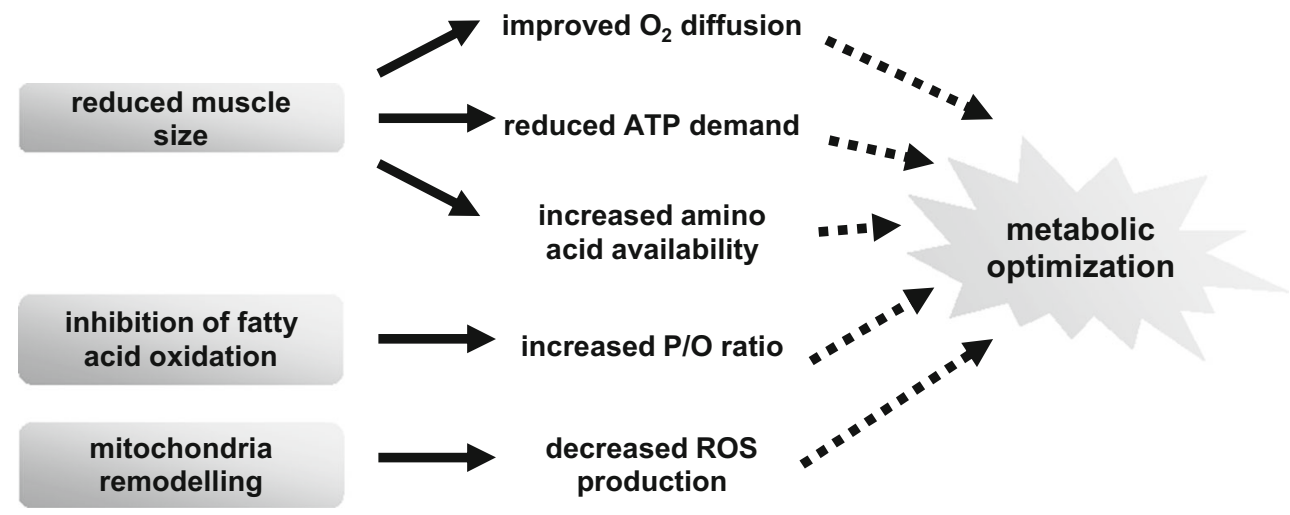

Fig. 5 Consequences of metabolic and structural adaptations on muscle homeostasis after hypoxia exposure. Reduced muscle size is mainly driven by the inhibition of the Akt/TORC1 pathway. HIF-1 inhibits the PPAR $\alpha /$ PGC- $1 \alpha$ axis resulting in a decrease in fatty acid

muscle mass and thus in whole body metabolic rate and the release of amino acids during muscle breakdown can also be beneficial to protect from hypoxia since they will act as metabolic fuel as well as metabolic modulator synergistically with ketone bodies [137].

\section{Conclusion and perspectives}

Hypoxia effects are primarily thought to be deleterious for skeletal muscle function, especially for mountaineers or active people who have to exercise at altitude. Nevertheless, structural and metabolic regulations that have been characterized result in metabolic optimization (Fig. 5) and are able to minimize the effects of decreased oxygen supply on muscle endurance. These effects are mainly related to HIF-1 $\alpha$, although it may be only transiently stabilized. Prolonged HIF- $1 \alpha$ expression could promote apoptosis [34] suggesting that successful acclimatization needs destabilization of HIF- $1 \alpha$, notably via reduced ROS production. However, data about HIF- $1 \alpha$ expression kinetics in skeletal muscle tissue of healthy subjects or patients with impaired $\mathrm{O}_{2}$ delivery are still lacking. The exact contribution of HIF-2 in hypoxia-induced adaptations also needs to be clarified, especially as it has been proposed in cancer cells that HIF-2 is more involved in chronic adaptation to hypoxia, while HIF-1 would mediate acute responses [138]. The role of miRNAs in hypoxic response has emerged into the field of cancer research, but this remains an unresolved question concerning muscle adaptations to low $\mathrm{O}_{2}$. Among the hypoxia-induced targets, miR-199a and -210 may be relevant candidates since they regulate muscle cell phenotype in a HIF-1-dependent way [83, 139]. Concerning experimental designs, it remains to determine whether hypobaric and normobaric hypoxia induce similar effects [140]. In addition, oxidation. Mitochondria remodelling includes UCP3 induction, the COX-1 to COX-2 shift as well as the stimulation of BNIP3-mediated mitophagy that removes altered mitochondria

extrapolation of data obtained on small animals to humans requires caution because of differences in $\mathrm{O}_{2}$ diffusion capacity. Identical $\mathrm{PIO}_{2}$ could have attenuated effects in rodents compared to patients explaining the use of extreme hypoxia in animal studies $[19,74]$. Despite the increasing number of people travelling to high altitude or suffering from pathologies associated with reduced $\mathrm{O}_{2}$ delivery, the response of human skeletal muscle to hypoxic episodes and its interplay with other organs is still an open challenge.

\section{References}

1. Rolfe DF, Brown GC (1997) Cellular energy utilization and molecular origin of standard metabolic rate in mammals. Physiol Rev 77:731-758

2. Richardson RS, Duteil S, Wary C et al (2006) Human skeletal muscle intracellular oxygenation: the impact of ambient oxygen availability. J Physiol 571:415-424. doi:10.1113/jphysiol.2005. 102327

3. Richardson RS, Noyszewski EA, Kendrick KF et al (1995) Myoglobin $\mathrm{O}_{2}$ desaturation during exercise. Evidence of limited $\mathrm{O}_{2}$ transport. J Clin Invest 96:1916-1926. doi:10.1172/ JCI118237

4. Johnson PC, Vandegriff K, Tsai AG, Intaglietta M (2005) Effect of acute hypoxia on microcirculatory and tissue oxygen levels in rat cremaster muscle. J Appl Physiol Bethesda Md 1985 98:1177-1184. doi:10.1152/japplphysiol.00591.2004

5. Hutter J, Habler O, Kleen M et al (1999) Effect of acute normovolemic hemodilution on distribution of blood flow and tissue oxygenation in dog skeletal muscle. J Appl Physiol Bethesda Md 1985 86:860-866

6. Jung F, Kessler H, Pindur G et al (1999) Intramuscular oxygen partial pressure in the healthy during exercise. Clin Hemorheol Microcirc 21:25-33

7. Masschelein E, Van Thienen R, D'Hulst G et al (2014) Acute environmental hypoxia induces LC3 lipidation in a genotypedependent manner. FASEB J Off Publ Fed Am Soc Exp Biol 28:1022-1034. doi:10.1096/fj.13-239863 
8. Richmond KN, Burnite S, Lynch RM (1997) Oxygen sensitivity of mitochondrial metabolic state in isolated skeletal and cardiac myocytes. Am J Physiol 273:C1613-C1622

9. Span PN, Bussink J (2015) Biology of hypoxia. Semin Nucl Med 45:101-109. doi:10.1053/j.semnuclmed.2014.10.002

10. Höckel M, Vaupel P (2001) Tumor hypoxia: definitions and current clinical, biologic, and molecular aspects. J Natl Cancer Inst 93:266-276

11. Semenza GL, Wang GL (1992) A nuclear factor induced by hypoxia via de novo protein synthesis binds to the human erythropoietin gene enhancer at a site required for transcriptional activation. Mol Cell Biol 12:5447-5454

12. Ke Q, Costa M (2006) Hypoxia-inducible factor-1 (HIF-1). Mol Pharmacol 70:1469-1480. doi:10.1124/mol.106.027029

13. Iyer NV, Kotch LE, Agani F et al (1998) Cellular and developmental control of $\mathrm{O}_{2}$ homeostasis by hypoxia-inducible factor 1 alpha. Genes Dev 12:149-162

14. Kline DD, Peng Y-J, Manalo DJ et al (2002) Defective carotid body function and impaired ventilatory responses to chronic hypoxia in mice partially deficient for hypoxia-inducible factor 1 alpha. Proc Natl Acad Sci USA 99:821-826. doi:10.1073/ pnas.022634199

15. Yu AY, Shimoda LA, Iyer NV et al (1999) Impaired physiological responses to chronic hypoxia in mice partially deficient for hypoxia-inducible factor 1alpha. J Clin Invest 103:691-696. doi:10.1172/JCI5912

16. Yu AY, Frid MG, Shimoda LA et al (1998) Temporal, spatial, and oxygen-regulated expression of hypoxia-inducible factor-1 in the lung. Am J Physiol 275:L818-L826

17. Lando D, Peet DJ, Whelan DA et al (2002) Asparagine hydroxylation of the HIF transactivation domain a hypoxic switch. Science 295:858-861. doi:10.1126/science.1068592

18. Chandel NS, McClintock DS, Feliciano CE et al (2000) Reactive oxygen species generated at mitochondrial complex III stabilize hypoxia-inducible factor-1alpha during hypoxia: a mechanism of $\mathrm{O}_{2}$ sensing. J Biol Chem 275:25130-25138. doi:10.1074/jbc.M001914200

19. Chaudhary P, Suryakumar G, Prasad R et al (2012) Chronic hypobaric hypoxia mediated skeletal muscle atrophy: role of ubiquitin-proteasome pathway and calpains. Mol Cell Biochem 364:101-113. doi:10.1007/s11010-011-1210-x

20. Wei W, Yu XD (2007) Hypoxia-inducible factors: crosstalk between their protein stability and protein degradation. Cancer Lett 257:145-156. doi:10.1016/j.canlet.2007.08.009

21. Kubis H-P, Hanke N, Scheibe RJ, Gros G (2005) Accumulation and nuclear import of HIF1 alpha during high and low oxygen concentration in skeletal muscle cells in primary culture. Biochim Biophys Acta 1745:187-195. doi:10.1016/j.bbamcr.2005.05.007

22. Mekhail K, Gunaratnam L, Bonicalzi M-E, Lee S (2004) HIF activation by $\mathrm{pH}$-dependent nucleolar sequestration of VHL. Nat Cell Biol 6:642-647. doi:10.1038/ncb1144

23. Van Uden P, Kenneth NS, Rocha S (2008) Regulation of hypoxia-inducible factor-1alpha by NF-kappaB. Biochem $\mathrm{J}$ 412:477-484. doi:10.1042/BJ20080476

24. Basic VT, Jacobsen A, Sirsjö A, Abdel-Halim SM (2014) TNF stimulation induces VHL overexpression and impairs angiogenic potential in skeletal muscle myocytes. Int $\mathrm{J}$ Mol Med 34:228-236. doi:10.3892/ijmm.2014.1776

25. Aragonés J, Schneider M, Van Geyte K et al (2008) Deficiency or inhibition of oxygen sensor Phd1 induces hypoxia tolerance by reprogramming basal metabolism. Nat Genet 40:170-180. doi:10.1038/ng.2007.62

26. Ameln H, Gustafsson T, Sundberg CJ et al (2005) Physiological activation of hypoxia inducible factor-1 in human skeletal muscle. FASEB J Off Publ Fed Am Soc Exp Biol 19:1009-1011. doi:10.1096/fj.04-2304fje
27. Rasbach KA, Gupta RK, Ruas JL et al (2010) PGC-1alpha regulates a HIF2alpha-dependent switch in skeletal muscle fiber types. Proc Natl Acad Sci USA 107:21866-21871. doi:10.1073/ pnas. 1016089107

28. Zhang P, Yao Q, Lu L et al (2014) Hypoxia-inducible factor 3 is an oxygen-dependent transcription activator and regulates a distinct transcriptional response to hypoxia. Cell Rep 6:1110-1121. doi:10.1016/j.celrep.2014.02.011

29. Makino Y, Kanopka A, Wilson WJ et al (2002) Inhibitory PAS domain protein (IPAS) is a hypoxia-inducible splicing variant of the hypoxia-inducible factor-3alpha locus. J Biol Chem 277:32405-32408. doi:10.1074/jbc.C200328200

30. Cummins EP, Taylor CT (2005) Hypoxia-responsive transcription factors. Pflüg Arch Eur J Physiol 450:363-371. doi:10. 1007/s00424-005-1413-7

31. Greijer AE, van der Groep P, Kemming D et al (2005) Upregulation of gene expression by hypoxia is mediated predominantly by hypoxia-inducible factor 1 (HIF-1). J Pathol 206:291-304. doi:10.1002/path.1778

32. Metzen E, Wolff M, Fandrey J, Jelkmann W (1995) Pericellular $\mathrm{PO}_{2}$ and $\mathrm{O}_{2}$ consumption in monolayer cell cultures. Respir Physiol 100:101-106

33. Nimker C, Kaur G, Revo A et al (2015) Ethyl 3,4-dihydroxy benzoate, a unique preconditioning agent for alleviating hypoxia-mediated oxidative damage in L6 myoblasts cells. J Physiol Sci JPS 65:77-87. doi:10.1007/s12576-014-0348-1

34. Bagnall J, Leedale J, Taylor SE et al (2014) Tight control of hypoxia-inducible factor- $\alpha$ transient dynamics is essential for cell survival in hypoxia. J Biol Chem 289:5549-5564. doi:10. 1074/jbc.M113.500405

35. Lindholm ME, Fischer H, Poellinger L et al (2014) Negative regulation of HIF in skeletal muscle of elite endurance athletes: a tentative mechanism promoting oxidative metabolism. Am J Physiol Regul Integr Comp Physiol 307:R248-R255. doi:10. 1152/ajpregu.00036.2013

36. Basic VT, Tadele E, Elmabsout AA et al (2012) Exposure to cigarette smoke induces overexpression of von Hippel-Lindau tumor suppressor in mouse skeletal muscle. Am J Physiol Lung Cell Mol Physiol 303:L519-L527. doi:10.1152/ajplung.00007.2012

37. Stroka DM, Burkhardt T, Desbaillets I et al (2001) HIF-1 is expressed in normoxic tissue and displays an organ-specific regulation under systemic hypoxia. FASEB J Off Publ Fed Am Soc Exp Biol 15:2445-2453. doi:10.1096/fj.01-0125com

38. Pirkmajer S, Filipovic D, Mars T et al (2010) HIF-1alpha response to hypoxia is functionally separated from the glucocorticoid stress response in the in vitro regenerating human skeletal muscle. Am J Physiol Regul Integr Comp Physiol 299:R1693-R1700. doi:10.1152/ajpregu.00133.2010

39. Badger JL, Byrne ML, Veraitch FS et al (2012) Hypoxic culture of human pluripotent stem cell lines is permissible using mouse embryonic fibroblasts. Regen Med 7:675-683. doi:10.2217/rme. 12.55

40. Hagström L, Agbulut O, El-Hasnaoui-Saadani R et al (2010) Epo is relevant neither for microvascular formation nor for the new formation and maintenance of mice skeletal muscle fibres in both normoxia and hypoxia. $\mathrm{J}$ Biomed Biotechnol 2010:137817. doi:10.1155/2010/137817

41. Tsui AKY, Marsden PA, Mazer CD et al (2014) Differential HIF and NOS responses to acute anemia: defining organ-specific hemoglobin thresholds for tissue hypoxia. Am J Physiol Regul Integr Comp Physiol 307:R13-R25. doi:10.1152/ajpregu.00411. 2013

42. Rupp T, Leti T, Jubeau M et al (2013) Tissue deoxygenation kinetics induced by prolonged hypoxic exposure in healthy humans at rest. J Biomed Opt 18:095002. doi:10.1117/1.JBO.18. 9.095002 
43. Lunde IG, Anton SL, Bruusgaard JC et al (2011) Hypoxia inducible factor 1 links fast-patterned muscle activity and fast muscle phenotype in rats. J Physiol 589:1443-1454. doi:10. 1113/jphysiol.2010.202762

44. Viganò A, Ripamonti M, De Palma S et al (2008) Proteins modulation in human skeletal muscle in the early phase of adaptation to hypobaric hypoxia. Proteomics 8:4668-4679. doi:10.1002/pmic.200800232

45. Lundby C, Calbet JAL, Robach P (2009) The response of human skeletal muscle tissue to hypoxia. Cell Mol Life Sci CMLS 66:3615-3623. doi:10.1007/s00018-009-0146-8

46. De Palma S, Ripamonti M, Vigano A et al (2007) Metabolic modulation induced by chronic hypoxia in rats using a comparative proteomic analysis of skeletal muscle tissue. J Proteome Res 6:1974-1984. doi:10.1021/pr060614o

47. Pisani DF, Dechesne CA (2005) Skeletal muscle HIF-1alpha expression is dependent on muscle fiber type. J Gen Physiol 126:173-178. doi:10.1085/jgp.200509265

48. Ahmetov II, Hakimullina AM, Lyubaeva EV et al (2008) Effect of HIF1A gene polymorphism on human muscle performance. Bull Exp Biol Med 146:351-353

49. Semenza GL (2001) HIF-1, O(2), and the 3 PHDs: how animal cells signal hypoxia to the nucleus. Cell 107:1-3

50. Horscroft JA, Murray AJ (2014) Skeletal muscle energy metabolism in environmental hypoxia: climbing towards consensus. Extreme Physiol Med. doi:10.1186/2046-7648-3-19

51. Ou LC, Leiter JC (2004) Effects of exposure to a simulated altitude of $5500 \mathrm{~m}$ on energy metabolic pathways in rats. Respir Physiol Neurobiol 141:59-71. doi:10.1016/j.resp.2004.04.001

52. Kim J, Tchernyshyov I, Semenza GL, Dang CV (2006) HIF-1mediated expression of pyruvate dehydrogenase kinase: a metabolic switch required for cellular adaptation to hypoxia. Cell Metab 3:177-185. doi:10.1016/j.cmet.2006.02.002

53. Le Moine CMR, Morash AJ, McClelland GB (2011) Changes in HIF- $1 \alpha$ protein, pyruvate dehydrogenase phosphorylation, and activity with exercise in acute and chronic hypoxia. Am J Physiol Regul Integr Comp Physiol 301:R1098-R1104. doi:10. 1152/ajpregu.00070.2011

54. Brooks GA, Wolfel EE, Butterfield GE et al (1998) Poor relationship between arterial [lactate] and leg net release during exercise at $4300 \mathrm{~m}$ altitude. Am J Physiol 275:R1192-R1201

55. Green HJ, Sutton JR, Wolfel EE et al (1992) Altitude acclimatization and energy metabolic adaptations in skeletal muscle during exercise. J Appl Physiol Bethesda Md 1985 73:2701-2708

56. Ullah MS, Davies AJ, Halestrap AP (2006) The plasma membrane lactate transporter MCT4, but not MCT1, is up-regulated by hypoxia through a HIF-1alpha-dependent mechanism. J Biol Chem 281:9030-9037. doi:10.1074/jbc.M511397200

57. Juel C, Lundby C, Sander M et al (2003) Human skeletal muscle and erythrocyte proteins involved in acid-base homeostasis: adaptations to chronic hypoxia. J Physiol 548:639-648. doi:10. 1113/jphysiol.2002.035899

58. McClelland GB, Brooks GA (2002) Changes in MCT 1, MCT 4, and LDH expression are tissue specific in rats after long-term hypobaric hypoxia. J Appl Physiol Bethesda Md 1985 92:1573-1584. doi:10.1152/japplphysiol.01069.2001

59. Py G, Eydoux N, Lambert K et al (2005) Role of hypoxiainduced anorexia and right ventricular hypertrophy on lactate transport and MCT expression in rat muscle. Metabolism 54:634-644. doi:10.1016/j.metabol.2004.12.007

60. Mason SD, Rundqvist H, Papandreou I et al (2007) HIF-1alpha in endurance training: suppression of oxidative metabolism. Am J Physiol Regul Integr Comp Physiol 293:R2059-R2069. doi:10. 1152/ajpregu.00335.2007

61. Belanger AJ, Luo Z, Vincent KA et al (2007) Hypoxia-inducible factor 1 mediates hypoxia-induced cardiomyocyte lipid accumulation by reducing the DNA binding activity of peroxisome proliferator-activated receptor alpha/retinoid $\mathrm{X}$ receptor. Biochem Biophys Res Commun 364:567-572. doi:10.1016/j. bbrc.2007.10.062

62. Huss JM, Levy FH, Kelly DP (2001) Hypoxia inhibits the peroxisome proliferator-activated receptor alpha/retinoid $\mathrm{X}$ receptor gene regulatory pathway in cardiac myocytes: a mechanism for $\mathrm{O}_{2}$-dependent modulation of mitochondrial fatty acid oxidation. J Biol Chem 276:27605-27612. doi:10.1074/jbc. M100277200

63. Regnault TRH, Zhao L, Chiu JSS et al (2010) Peroxisome proliferator-activated receptor $-\beta / \delta,-\gamma$ agonists and resveratrol modulate hypoxia induced changes in nuclear receptor activators of muscle oxidative metabolism. PPAR Res 2010:129173. doi: $10.1155 / 2010 / 129173$

64. Slot IGM, Schols AMWJ, Vosse BAH et al (2014) Hypoxia differentially regulates muscle oxidative fiber type and metabolism in a HIF-1 $\alpha$-dependent manner. Cell Signal 26:1837-1845. doi:10.1016/j.cellsig.2014.04.016

65. Chaillou T, Koulmann N, Meunier A et al (2013) Effect of hypoxia exposure on the phenotypic adaptation in remodelling skeletal muscle submitted to functional overload. Acta Physiol Oxf Engl 209:272-282. doi:10.1111/apha.12110

66. Dutta A, Vats P, Singh VK et al (2009) Impairment of mitochondrial beta-oxidation in rats under cold-hypoxic environment. Int J Biometeorol 53:397-407. doi:10.1007/ s00484-009-0224-5

67. Morash AJ, Kotwica AO, Murray AJ (2013) Tissue-specific changes in fatty acid oxidation in hypoxic heart and skeletal muscle. Am J Physiol Regul Integr Comp Physiol 305:R534R541. doi:10.1152/ajpregu.00510.2012

68. Hoppeler H, Kleinert E, Schlegel C et al (1990) Morphological adaptations of human skeletal muscle to chronic hypoxia. Int J Sports Med 11(Suppl 1):S3-S9. doi:10.1055/s-2007-1024846

69. Levett DZ, Radford EJ, Menassa DA et al (2012) Acclimatization of skeletal muscle mitochondria to high-altitude hypoxia during an ascent of Everest. FASEB J Off Publ Fed Am Soc Exp Biol 26:1431-1441. doi:10.1096/fj.11-197772

70. Hoppeler H, Vogt M (2001) Muscle tissue adaptations to hypoxia. J Exp Biol 204:3133-3139

71. Zhang H, Bosch-Marce M, Shimoda LA et al (2008) Mitochondrial autophagy is an HIF-1-dependent adaptive metabolic response to hypoxia. J Biol Chem 283:10892-10903. doi:10. 1074/jbc.M800102200

72. Band M, Joel A, Hernandez A, Avivi A (2009) Hypoxia-induced BNIP3 expression and mitophagy: in vivo comparison of the rat and the hypoxia-tolerant mole rat, Spalax ehrenbergi. FASEB J Off Publ Fed Am Soc Exp Biol 23:2327-2335. doi:10.1096/fj. 08-122978

73. Gamboa JL, Garcia-Cazarin ML, Andrade FH (2011) Chronic hypoxia increases insulin-stimulated glucose uptake in mouse soleus muscle. Am J Physiol Regul Integr Comp Physiol 300:R85-R91. doi:10.1152/ajpregu.00078.2010

74. De Theije CC, Langen RCJ, Lamers WH et al (2013) Distinct responses of protein turnover regulatory pathways in hypoxiaand semistarvation-induced muscle atrophy. Am J Physiol Lung Cell Mol Physiol 305:L82-L91. doi:10.1152/ajplung.00354. 2012

75. Bellot G, Garcia-Medina R, Gounon P et al (2009) Hypoxiainduced autophagy is mediated through hypoxia-inducible factor induction of BNIP3 and BNIP3L via their BH3 domains. Mol Cell Biol 29:2570-2581. doi:10.1128/MCB.00166-09

76. Chen R, Dioum EM, Hogg RT et al (2011) Hypoxia increases sirtuin 1 expression in a hypoxia-inducible factor-dependent manner. J Biol Chem 286:13869-13878. doi:10.1074/jbc.M110. 175414 
77. Kume S, Uzu T, Horiike $\mathrm{K}$ et al (2010) Calorie restriction enhances cell adaptation to hypoxia through Sirt1-dependent mitochondrial autophagy in mouse aged kidney. J Clin Invest 120:1043-1055. doi:10.1172/JCI41376

78. Lokireddy S, Wijesoma IW, Teng S et al (2012) The ubiquitin ligase Mul1 induces mitophagy in skeletal muscle in response to muscle-wasting stimuli. Cell Metab 16:613-624. doi:10.1016/j. cmet.2012.10.005

79. Mason SD, Howlett RA, Kim MJ et al (2004) Loss of skeletal muscle HIF-1alpha results in altered exercise endurance. PLoS Biol 2:e288. doi:10.1371/journal.pbio.0020288

80. Fukuda R, Zhang H, Kim J et al (2007) HIF-1 regulates cytochrome oxidase subunits to optimize efficiency of respiration in hypoxic cells. Cell 129:111-122. doi:10.1016/j.cell.2007.01.047

81. Bo H, Wang Y-H, Li H-Y et al (2008) Endurance training attenuates the bioenergetics alterations of rat skeletal muscle mitochondria submitted to acute hypoxia: role of ROS and UCP3. Sheng Li Xue Bao 60:767-776

82. Lu Z, Sack MN (2008) ATF-1 is a hypoxia-responsive transcriptional activator of skeletal muscle mitochondrialuncoupling protein 3. J Biol Chem 283:23410-23418. doi:10. 1074/jbc.M801236200

83. Cicchillitti L, Di Stefano V, Isaia E et al (2012) Hypoxia-inducible factor $1-\alpha$ induces miR-210 in normoxic differentiating myoblasts. J Biol Chem 287:44761-44771. doi:10.1074/jbc. M112.421255

84. Gelfi C, De Palma S, Ripamonti M et al (2004) New aspects of altitude adaptation in Tibetans: a proteomic approach. FASEB J Off Publ Fed Am Soc Exp Biol 18:612-614. doi:10.1096/fj.031077fje

85. Saxena S, Shukla D, Saxena S et al (2010) Hypoxia preconditioning by cobalt chloride enhances endurance performance and protects skeletal muscles from exercise-induced oxidative damage in rats. Acta Physiol Oxf Engl 200:249-263. doi:10. 1111/j.1748-1716.2010.02136.x

86. Galbès O, Goret L, Caillaud C et al (2008) Combined effects of hypoxia and endurance training on lipid metabolism in rat skeletal muscle. Acta Physiol Oxf Engl 193:163-173. doi:10. 1111/j.1748-1716.2007.01794.x

87. Gamboa JL, Andrade FH (2012) Muscle endurance and mitochondrial function after chronic normobaric hypoxia: contrast of respiratory and limb muscles. Pflüg Arch Eur J Physiol 463:327-338. doi:10.1007/s00424-011-1057-8

88. Magalhães J, Ascensão A, Soares JMC et al (2005) Acute and severe hypobaric hypoxia increases oxidative stress and impairs mitochondrial function in mouse skeletal muscle. J Appl Physiol Bethesda Md 1985 99:1247-1253. doi:10.1152/japplphysiol. 01324.2004

89. Jacobs RA, Boushel R, Wright-Paradis C et al (2013) Mitochondrial function in human skeletal muscle following highaltitude exposure. Exp Physiol 98:245-255. doi:10.1113/ expphysiol.2012.066092

90. Bigard AX, Brunet A, Guezennec CY, Monod H (1991) Effects of chronic hypoxia and endurance training on muscle capillarity in rats. Pflüg Arch Eur J Physiol 419:225-229

91. Green HJ, Sutton JR, Cymerman A et al (1989) Operation Everest II: adaptations in human skeletal muscle. J Appl Physiol Bethesda Md 1985 66:2454-2461

92. Snyder GK, Farrelly C, Coelho JR (1992) Adaptations in skeletal muscle capillarity following changes in oxygen supply and changes in oxygen demands. Eur J Appl Physiol 65:158-163

93. Niemi H, Honkonen K, Korpisalo P et al (2014) HIF-1 $\alpha$ and HIF- $2 \alpha$ induce angiogenesis and improve muscle energy recovery. Eur J Clin Invest 44:989-999. doi:10.1111/eci.12333

94. Olfert IM, Breen EC, Mathieu-Costello O, Wagner PD (2001) Skeletal muscle capillarity and angiogenic mRNA levels after exercise training in normoxia and chronic hypoxia. J Appl Physiol Bethesda Md 1985 91:1176-1184

95. Lundby C, Pilegaard H, Andersen JL et al (2004) Acclimatization to $4100 \mathrm{~m}$ does not change capillary density or mRNA expression of potential angiogenesis regulatory factors in human skeletal muscle. J Exp Biol 207:3865-3871. doi:10.1242/jeb. 01225

96. MacDougall JD, Green HJ, Sutton JR et al (1991) Operation Everest II: structural adaptations in skeletal muscle in response to extreme simulated altitude. Acta Physiol Scand 142:421-427. doi:10.1111/j.1748-1716.1991.tb09176.x

97. Sillau AH, Aquin L, Bui MV, Banchero N (1980) Chronic hypoxia does not affect guinea pig skeletal muscle capillarity. Pflüg Arch Eur J Physiol 386:39-45

98. Hoppeler H, Vogt M, Weibel ER, Flück M (2003) Response of skeletal muscle mitochondria to hypoxia. Exp Physiol 88:109-119

99. Kayser B, Narici M, Binzoni T et al (1994) Fatigue and exhaustion in chronic hypobaric hypoxia: influence of exercising muscle mass. J Appl Physiol Bethesda Md 1985 76:634-640

100. Bigard AX, Douce P, Merino D et al (1996) Changes in dietary protein intake fail to prevent decrease in muscle growth induced by severe hypoxia in rats. J Appl Physiol Bethesda Md 1985 $80: 208-215$

101. Favier FB, Costes F, Defour A et al (2010) Downregulation of Akt/mammalian target of rapamycin pathway in skeletal muscle is associated with increased REDD1 expression in response to chronic hypoxia. Am J Physiol Regul Integr Comp Physiol 298:R1659-R1666. doi:10.1152/ajpregu.00550.2009

102. al-Amood WS, Lewis DM (1989) A comparison of the effects of denervation on the mechanical properties of rat and guinea-pig skeletal muscle. J Physiol 414:1-16

103. Nilwik R, Snijders T, Leenders $M$ et al (2013) The decline in skeletal muscle mass with aging is mainly attributed to a reduction in type II muscle fiber size. Exp Gerontol 48:492-498. doi:10.1016/j.exger.2013.02.012

104. Shimizu N, Yoshikawa N, Ito N et al (2011) Crosstalk between glucocorticoid receptor and nutritional sensor mTOR in skeletal muscle. Cell Metab 13:170-182. doi:10.1016/j.cmet.2011.01. 001

105. Pistilli EE, Bogdanovich S, Mosqueira M et al (2010) Pretreatment with a soluble activin type IIB receptor/Fc fusion protein improves hypoxia-induced muscle dysfunction. Am J Physiol Regul Integr Comp Physiol 298:R96-R103. doi:10. 1152/ajpregu.00138.2009

106. De Theije CC, Langen RCJ, Lamers WH et al (2014) Differential sensitivity of oxidative and glycolytic muscles to hypoxiainduced muscle atrophy. J Appl Physiol Bethesda Md 1985. doi:10.1152/japplphysiol.00624.2014

107. Hoppeler H (1986) Exercise-induced ultrastructural changes in skeletal muscle. Int J Sports Med 7:187-204. doi:10.1055/s2008-1025758

108. Arthur PG, Giles JJ, Wakeford CM (2000) Protein synthesis during oxygen conformance and severe hypoxia in the mouse muscle cell line C2C12. Biochim Biophys Acta 1475:83-89

109. Preedy VR, Smith DM, Sugden PH (1985) The effects of 6 hours of hypoxia on protein synthesis in rat tissues in vivo and in vitro. Biochem J 228:179-185

110. Holm L, Haslund ML, Robach P et al (2010) Skeletal muscle myofibrillar and sarcoplasmic protein synthesis rates are affected differently by altitude-induced hypoxia in native lowlanders. PLoS One 5:e15606. doi:10.1371/journal.pone.0015606

111. Imoberdorf R, Garlick PJ, McNurlan MA et al (2006) Skeletal muscle protein synthesis after active or passive ascent to high altitude. Med Sci Sports Exerc 38:1082-1087. doi:10.1249/01. mss.0000222836.66391.35 
112. Etheridge T, Atherton PJ, Wilkinson D et al (2011) Effects of hypoxia on muscle protein synthesis and anabolic signaling at rest and in response to acute resistance exercise. Am J Physiol Endocrinol Metab 301:E697-E702. doi:10.1152/ajpendo.00276.2011

113. Bodine SC, Stitt TN, Gonzalez M et al (2001) Akt/mTOR pathway is a crucial regulator of skeletal muscle hypertrophy and can prevent muscle atrophy in vivo. Nat Cell Biol 3:1014-1019. doi:10.1038/ncb1101-1014

114. Rommel C, Bodine SC, Clarke BA et al (2001) Mediation of IGF-1-induced skeletal myotube hypertrophy by PI(3)K/Akt/ mTOR and PI(3)K/Akt/GSK3 pathways. Nat Cell Biol 3:1009-1013. doi:10.1038/ncb1101-1009

115. Costes F, Gosker HR, Féasson L et al (2015) Impaired exercise training-induced muscle fiber hypertrophy and Akt/mTOR pathway activation in hypoxemic COPD patients. J Appl Physiol Bethesda Md 1985. doi:10.1152/japplphysiol.00557.2014

116. Amirouche A, Durieux A-C, Banzet S et al (2009) Down-regulation of Akt/mammalian target of rapamycin signaling pathway in response to myostatin overexpression in skeletal muscle. Endocrinology 150:286-294. doi:10.1210/en.2008-0959

117. Trendelenburg AU, Meyer A, Rohner D et al (2009) Myostatin reduces Akt/TORC1/p70S6K signaling, inhibiting myoblast differentiation and myotube size. Am J Physiol Cell Physiol 296:C1258-C1270. doi:10.1152/ajpcell.00105.2009

118. Chaillou T, Koulmann N, Simler N et al (2012) Hypoxia transiently affects skeletal muscle hypertrophy in a functional overload model. Am J Physiol Regul Integr Comp Physiol 302:R643-R654. doi:10.1152/ajpregu.00262.2011

119. Hayot M, Rodriguez J, Vernus B et al (2011) Myostatin upregulation is associated with the skeletal muscle response to hypoxic stimuli. Mol Cell Endocrinol 332:38-47. doi:10.1016/j. mce.2010.09.008

120. Van den Borst B, Schols AMWJ, de Theije C et al (2013) Characterization of the inflammatory and metabolic profile of adipose tissue in a mouse model of chronic hypoxia. J Appl Physiol Bethesda Md 1985 114:1619-1628. doi:10.1152/ japplphysiol.00460.2012

121. Sanchez AMJ, Csibi A, Raibon A et al (2012) AMPK promotes skeletal muscle autophagy through activation of forkhead FoxO3a and interaction with Ulk1. J Cell Biochem 113:695-710. doi:10.1002/jcb.23399

122. Wadley GD, Lee-Young RS, Canny BJ et al (2006) Effect of exercise intensity and hypoxia on skeletal muscle AMPK signaling and substrate metabolism in humans. Am J Physiol Endocrinol Metab 290:E694-E702. doi:10.1152/ajpendo.00464.2005

123. Chaillou T, Koulmann N, Meunier A et al (2014) Ambient hypoxia enhances the loss of muscle mass after extensive injury. Pflüg Arch Eur J Physiol 466:587-598. doi:10.1007/s00424013-1336-7

124. Britto FA, Begue G, Rossano B et al (2014) REDD1 deletion prevents dexamethasone-induced skeletal muscle atrophy. Am J Physiol Endocrinol Metab 307:E983-E993. doi:10.1152/ ajpendo.00234.2014

125. D'Hulst G, Jamart C, Van Thienen R et al (2013) Effect of acute environmental hypoxia on protein metabolism in human skeletal muscle. Acta Physiol Oxf Engl 208:251-264. doi:10.1111/apha. 12086

126. Horak P, Crawford AR, Vadysirisack DD et al (2010) Negative feedback control of HIF-1 through REDD1-regulated ROS suppresses tumorigenesis. Proc Natl Acad Sci USA 107:4675-4680. doi:10.1073/pnas.0907705107

127. Li Y, Wang Y, Kim E et al (2007) Bnip3 mediates the hypoxiainduced inhibition on mammalian target of rapamycin by interacting with Rheb. J Biol Chem 282:35803-35813. doi:10. 1074/jbc.M705231200
128. Koumenis C, Naczki C, Koritzinsky M et al (2002) Regulation of protein synthesis by hypoxia via activation of the endoplasmic reticulum kinase PERK and phosphorylation of the translation initiation factor eIF2alpha. Mol Cell Biol 22:7405-7416

129. Bodine SC, Baehr LM (2014) Skeletal muscle atrophy and the E3 ubiquitin ligases MuRF1 and MAFbx/atrogin-1. Am J Physiol Endocrinol Metab 307:E469-E484. doi:10.1152/ ajpendo.00204.2014

130. Gille T, Randrianarison-Pellan N, Goolaerts A et al (2014) Hypoxia-induced inhibition of epithelial $\mathrm{Na}(+)$ channels in the lung. Role of Nedd4-2 and the ubiquitin-proteasome pathway. Am J Respir Cell Mol Biol 50:526-537. doi:10.1165/rcmb. 2012-0518OC

131. Köditz J, Nesper J, Wottawa M et al (2007) Oxygen-dependent ATF-4 stability is mediated by the PHD3 oxygen sensor. Blood 110:3610-3617. doi:10.1182/blood-2007-06-094441

132. Elvidge GP, Glenny L, Appelhoff RJ et al (2006) Concordant regulation of gene expression by hypoxia and 2-oxoglutaratedependent dioxygenase inhibition: the role of HIF-1alpha, HIF2alpha, and other pathways. J Biol Chem 281:15215-15226. doi:10.1074/jbc.M511408200

133. Cummins EP, Berra E, Comerford KM et al (2006) Prolyl hydroxylase-1 negatively regulates IkappaB kinase-beta, giving insight into hypoxia-induced NFkappaB activity. Proc Natl Acad Sci USA 103:18154-18159. doi:10.1073/pnas.0602235103

134. Ebert SM, Dyle MC, Kunkel SD et al (2012) Stress-induced skeletal muscle Gadd45a expression reprograms myonuclei and causes muscle atrophy. J Biol Chem 287:27290-27301. doi:10. 1074/jbc.M112.374777

135. Fox DK, Ebert SM, Bongers KS et al (2014) p53 and ATF4 mediate distinct and additive pathways to skeletal muscle atrophy during limb immobilization. Am J Physiol Endocrinol Metab 307:E245-E261. doi:10.1152/ajpendo.00010.2014

136. Cai D, Frantz JD, Tawa NE et al (2004) IKKbeta/NF-kappaB activation causes severe muscle wasting in mice. Cell 119:285-298. doi:10.1016/j.cell.2004.09.027

137. Murray AJ, Montgomery HE (2014) How wasting is saving: weight loss at altitude might result from an evolutionary adaptation. Bioessays News Rev Mol Cell Dev Biol 36:721-729. doi:10.1002/bies.201400042

138. Uchida T, Rossignol F, Matthay MA et al (2004) Prolonged hypoxia differentially regulates hypoxia-inducible factor (HIF)1alpha and HIF-2alpha expression in lung epithelial cells: implication of natural antisense HIF-1alpha. J Biol Chem 279:14871-14878. doi:10.1074/jbc.M400461200

139. Rane S, He M, Sayed D et al (2009) Downregulation of miR199a derepresses hypoxia-inducible factor-1alpha and Sirtuin 1 and recapitulates hypoxia preconditioning in cardiac myocytes. Circ Res 104:879-886. doi:10.1161/CIRCRESAHA.108.193102

140. Girard O, Koehle MS, MacInnis MJ et al (2012) Comments on point: counterpoint: hypobaric hypoxia induces/does not induce different responses from normobaric hypoxia. J Appl Physiol Bethesda Md 1985 112:1788-1794. doi:10.1152/japplphysiol. 00356.2012

141. Mizuno M, Juel C, Bro-Rasmussen T et al (1990) Limb skeletal muscle adaptation in athletes after training at altitude. J Appl Physiol Bethesda Md 1985 68:496-502

142. Abdelmalki A, Fimbel S, Mayet-Sornay MH et al (1996) Aerobic capacity and skeletal muscle properties of normoxic and hypoxic rats in response to training. Pflüg Arch Eur J Physiol 431:671-679

143. Bigard AX, Brunet A, Guezennec CY, Monod H (1991) Skeletal muscle changes after endurance training at high altitude. J Appl Physiol Bethesda Md 1985 71:2114-2121 
144. Young AJ, Evans WJ, Fisher EC et al (1984) Skeletal muscle metabolism of sea-level natives following short-term high-altitude residence. Eur J Appl Physiol 52:463-466

145. Kennedy SL, Stanley WC, Panchal AR, Mazzeo RS (2001) Alterations in enzymes involved in fat metabolism after acute and chronic altitude exposure. J Appl Physiol Bethesda Md 1985 90:17-22

146. Dill RP, Chadan SG, Li C, Parkhouse WS (2001) Aging and glucose transporter plasticity in response to hypobaric hypoxia. Mech Ageing Dev 122:533-545

147. Howald H, Hoppeler H (2003) Performing at extreme altitude: muscle cellular and subcellular adaptations. Eur J Appl Physiol 90:360-364. doi:10.1007/s00421-003-0872-9

148. Ripamonti M, Viganò A, Moriggi M et al (2006) Cytochrome $\mathrm{c}$ oxidase expression in chronic and intermittent hypoxia rat gastrocnemius muscle quantitated by CE. Electrophoresis 27:3897-3903. doi:10.1002/elps.200600104

149. Daneshrad Z, Garcia-Riera MP, Verdys M, Rossi A (2000) Differential responses to chronic hypoxia and dietary restriction of aerobic capacity and enzyme levels in the rat myocardium. Mol Cell Biochem 210:159-166
150. Green H, Roy B, Grant S et al (2000) Human skeletal muscle exercise metabolism following an expedition to mount denali. Am J Physiol Regul Integr Comp Physiol 279:R1872-R1879

151. Bigard AX, Sanchez H, Birot O, Serrurier B (2000) Myosin heavy chain composition of skeletal muscles in young rats growing under hypobaric hypoxia conditions. J Appl Physiol Bethesda Md 1985 88:479-486

152. Deveci D, Marshall JM, Egginton S (2002) Chronic hypoxia induces prolonged angiogenesis in skeletal muscles of rat. Exp Physiol 87:287-291

153. Faucher M, Guillot C, Marqueste T et al (2005) Matched adaptations of electrophysiological, physiological, and histological properties of skeletal muscles in response to chronic hypoxia. Pflüg Arch Eur J Physiol 450:45-52. doi:10.1007/s00424-004-1370-6

154. Sillau AH, Banchero N (1977) Effects of hypoxia on capillary density and fiber composition in rat skeletal muscle. Pflüg Arch Eur J Physiol 370:227-232

155. Wüst RCI, Jaspers RT, van Heijst AF et al (2009) Regionspecific adaptations in determinants of rat skeletal muscle oxygenation to chronic hypoxia. Am J Physiol Heart Circ Physiol 297:H364-H374. doi:10.1152/ajpheart.00272.2009 